\title{
Natural Products of Pharmacology and Mechanisms in Nucleus Pulposus Cells and Intervertebral Disc Degeneration
}

\author{
Hai-Wei Chen $\mathbb{D D}^{1,2}$ Guang-Zhi Zhang $\mathbb{D}^{1,,^{1,2}}$ Ming-Qiang Liu $\mathbb{D}^{1,2}$ Li-Juan Zhang, ${ }^{2,3}$ \\ Ji-He Kang, ${ }^{1,2}$ Zhao-Heng Wang, ${ }^{1,2}$ Wen-Zhao Liu, ${ }^{1,2}$ Ai-Xin Lin,,2 \\ and Xue-Wen Kang $\mathbb{D}^{1,3,4,5}$ \\ ${ }^{1}$ Department of Orthopedics, Lanzhou University Second Hospital, Lanzhou, Gansu 730000, China \\ ${ }^{2}$ The Second Clinical Medical College, Lanzhou University, Lanzhou, Gansu 730000, China \\ ${ }^{3}$ Department of Endocrinology, Lanzhou University Second Hospital, Lanzhou, Gansu 730000, China \\ ${ }^{4}$ Key Laboratory of Orthopedics Disease of Gansu Province, Lanzhou University Second Hospital, Lanzhou, \\ Gansu Province 730030, China \\ ${ }^{5}$ The International Cooperation Base of Gansu Province for The Pain Research in Spinal Disorders, Lanzhou, \\ Gansu Province 730030, China
}

Correspondence should be addressed to Xue-Wen Kang; ery_kangxw@lzu.edu.cn

Received 15 April 2021; Accepted 26 July 2021; Published 4 August 2021

Academic Editor: Barbara Romano

Copyright (C) 2021 Hai-Wei Chen et al. This is an open access article distributed under the Creative Commons Attribution License, which permits unrestricted use, distribution, and reproduction in any medium, provided the original work is properly cited.

Intervertebral disc degeneration (IDD) is one of the main causes of low back pain (LBP), which severely reduces the quality of life and imposes a heavy financial burden on the families of affected individuals. Current research suggests that IDD is a complex cellmediated process. Inflammation, oxidative stress, mitochondrial dysfunction, abnormal mechanical load, telomere shortening, DNA damage, and nutrient deprivation contribute to intervertebral disc cell senescence and changes in matrix metabolism, ultimately causing IDD. Natural products are widespread, structurally diverse, afford unique advantages, and exhibit great potential in terms of IDD treatment. In recent years, increasing numbers of natural ingredients have been shown to inhibit the degeneration of nucleus pulposus cells through various modes of action. Here, we review the pharmacological effects of natural products on nucleus pulposus cells and the mechanisms involved. An improved understanding of how natural products target signalling pathways will aid the development of anti-IDD drugs. This review focuses on potential IDD drugs.

\section{Introduction}

Low back pain is a symptom of intervertebral disc degeneration (IDD). Approximately $70 \%$ to $85 \%$ of people will experience low back pain or neck pain at least once in their lives, which severely reduces their quality of life [1]. Dieleman et al. reported that, among the populations with the highest medical expenditures from 1996 to 2016, patients with low back pain, neck pain, and diabetes comprised the greatest proportions. Moreover, the total cost of back pain, neck pain, and other musculoskeletal diseases is $\$ 264.3$ billion, which constitutes a considerable economic burden both to society and to the families of affected individuals [2]. IDD is mainly characterised by the degradation of extracellular matrix (ECM) and the loss of nucleus pulposus (NP) cells [3]. However, the specific pathogenesis of IDD is not fully understood. Current research indicates that IDD is a complex process that ultimately leads to changes in cell function and structure [4]. Notably, inflammation, oxidative stress, mitochondrial dysfunction, abnormal mechanical load, telomere shortening, DNA damage, and nutrient deprivation are involved in intervertebral disc cell senescence and altered matrix metabolism, which ultimately lead to the development of IDD [5].

Currently, therapeutic approaches for patients with IDD symptoms include conservative treatment and surgical intervention, although there is no cure or established method of disease management [6]. Therefore, safe and effective IDD treatment methods require further exploration. Mesenchymal stem cells [7], tissue engineering technology [8], 
growth factor therapy [9], exosomes [10], and biomaterial therapy [11] are currently the most compelling research avenues for IDD treatment. Although these approaches are novel and have great potential for further development, their clinical applications remain challenging.

Natural products are derived from plants, animals, and microorganisms [12]. Natural products of plant origin exhibit powerful pharmacological activities. Ophiorrhiza rugosa leaves reduce chemical and heat-induced inflammation [13]. Spirulina (a "superfood") exhibits great potential for treatment of inflammatory diseases [14]. The structural diversity of natural products is associated with many different pharmacological activities and functions; the materials interact with various proteins and other biological molecules [15-17]. There has been increasing attention towards the pharmacological effects of natural products on NP cells and the mechanisms involved. Many plant compounds inhibit NP cell senescence and apoptosis $[18,19]$. Here, we review these findings and offer suggestions for the development of anti-IDD drugs.

\section{Pathophysiology of IDD}

In healthy individuals, the intervertebral disc is a fibrocartilage structure consisting of three parts: the central NP, peripheral annulus fibrosus, and cartilage endplate (CEP) on both sides $[20,21]$. The NP is mainly composed of ECM rich in type II collagen, elastin, and proteoglycan. This area mainly acts to offset and transmit axial pressure load during stress to the spine. In contrast, the ECM of annulus fibrosus cells is mainly composed of alternating type I collagen fibres. Their main function is to prevent the NP from protruding under pressure during bending or twisting of the spine. Finally, the CEP is hyaline cartilage tissue with uniform thickness, and its ECM is mainly composed of proteoglycans and collagen fibres [22-24]. Because the intervertebral disc is an avascular and non-nervous tissue, the CEP plays an important role in nutrient supply to the intervertebral disc. Most nutrient exchanges and metabolic wastes occur through the CEP to maintain normal intervertebral disc structure and function [22]. As IDD progresses, the local metabolic status changes for intervertebral disc NP cells, annulus fibrosus cells, and CEP cells. These alterations involve reduced anabolism and enhanced catabolism, which lead to greater ECM degradation, diminished NP water content, lowered annulus fibrosus elasticity, and increased CEP calcification. These changes ultimately lead to pathological changes such as poor spinal stability, intervertebral disc collapse, spondylolisthesis, osteophyte formation, annulus fibrosus tearing, and NP tissue protrusion, all of which combine to cause low back pain [25-27]. The main causes of IDD are described below.

2.1. Inflammation. Inflammation is a pathological process that occurs after infection or injury. During inflammation, cells can secrete various inflammatory factors (e.g., TNF- $\alpha$, IL- $1 \alpha / \beta$, IL-6, IL-8, IL-2, IL-17, IL-10, IL-4, IFN- $\gamma$, and PGE2). These factors become involved in a series of inflammatory reactions that promote ECM degradation, autophagy, aging, and intervertebral disc cell apoptosis, thereby causing intervertebral disc dysfunction and structural changes $[6,28,29]$.

2.2. Oxidative Stress. Cellular aerobic metabolism is an important component of cell structure and function, and reactive oxygen species (ROS) are the main metabolic byproducts. With the development of IDD, the weakened antioxidant capacity in the intervertebral disc causes ROS aggregation. This leads to oxidative stress and activation of various IDD signalling pathways, which accelerate cell apoptosis, senescence, and ECM catabolism [30,31].

2.3. Mitochondrial Dysfunction. Mitophagy eliminates excessive ROS to maintain mitochondrial homeostasis, but mitochondrial DNA damage generates excessive stress signals and increases the ROS content. Excessive ROS levels eventually lead to mitochondrial dysfunction, trigger programmed cell death, and accelerate the progression of IDD [32-34].

2.4. Abnormal Mechanical Load. In a healthy intervertebral disc, appropriate biomechanical stress and hydrostatic pressure are necessary to maintain intervertebral disc homeostasis. When they are mechanically overloaded, cells within the intervertebral disc stop producing proteoglycans, thereby reducing pressure in the intervertebral disc and increasing the shearing force in the NP. This greater shear force further reduces proteoglycan production, forming a vicious circle that accelerates IDD $[35,36]$.

2.5. Telomere Shortening and DNA Damage. During continuous cell growth and division, incomplete replication of DNA ends and reduced telomerase activity leads to shortened telomere length and changes in DNA structure. Additional DNA damage due to exogenous factors can activate cell senescence mechanisms and lead to intervertebral disc cell rigidity $[5,37]$.

2.6. Nutritional Deprivation. Intervertebral discs are tissues without blood vessels and nerves. Most intervertebral disc nutrients and metabolic wastes are exchanged by diffusion through the CEP. A reduction in the nutrient supply leads to a diminished oxygen level and elevated lactic acid concentration, which changes $\mathrm{pH}$, affects cell function, and alters ECM synthesis [5, 22, 38].

\section{Natural Pharmacological Products}

Natural products are mainly extracted from various herbs. These products are structurally divided into six categories: phenolics, flavonoids, alkaloids, terpenoids, saponins, and quinones. They regulate oxidative stress, inflammation, apoptosis, and matrix metabolism through different mechanisms. Oxidative stress compromises NP cell function [31]. Natural products can downregulate mitochondrial ROS 
levels, increase SOD activity and the expression of mitochondrial cytochrome $c$, and protect cells from oxidative stress. Inflammation also compromises NP cell activity [39]. Natural products inhibit the expression of inflammatory factors IL- $1 \beta$, TNF- $\alpha$, COX-2, iNOS, PGE2, and IL-6, thereby reducing cell damage caused by inflammation. Apoptosis (programmed cell death) is a key regulator of NP cell activities [40]. The proapoptotic proteins include Bax, caspase-3, and caspase-9; antiapoptotic proteins include Bcl2. The ECM maintains intervertebral disc function and stability; a disintegrin, a metalloproteinase with a thrombospondin motif (ADAMTS), and other matrix metalloproteinases (MMPs) mediate both ECM degradation and synthesis [41]. Natural products inhibit the expression of MMP1, MMP3, MMP13, ADAMTS-4, and ADAMTS-5, thereby promoting collagen II and aggrecan synthesis. Here, we briefly introduce the pharmacological effects and molecular mechanisms of these six types of natural compounds in the treatment of IDD.

\subsection{Phenolics}

3.1.1. Resveratrol. Resveratrol (RES) is a naturally occurring polyphenol compound that exists in various plants and is mainly extracted from cinnamon bark, gourd, and polygonum cuspidatum. It has antioxidant, anti-inflammatory, antiaging, and autophagy-regulating effects, as well as the ability to reduce mechanical pain $[42,43]$. Wang et al. [18] reported that RES activates the Nrf2/Heme oxygenase 1 signalling pathway in rat NP cells, reducing ROS levels, slowing NP cell senescence, and enhancing NP cell matrix anabolism. Jiang et al. [44, 45] found that RES activates the PI3K/Akt pathway to inhibit cell apoptosis during IL- $1 \beta$-mediated inflammation. RES has been shown to reduce mechanical overload damage in a dose-dependent manner and regulate NP cell apoptosis by inhibiting activation of the ERK1/2 pathway [46]. It also inhibits the ROS/NF- $\kappa$ B signalling pathway and slows NP degeneration [47]. RES can upregulate SIRT1 (a member of the $\mathrm{NAD}^{+}$-dependent histone deacetylase family, involved in age-related diseases, cancers, and degenerative diseases [34]), which inhibits the p21/p16 pathway and regulates NP cell senescence [48]. In addition, RES can activate autophagy through the AMPK/SIRT1 axis and control cell matrix metabolism [49]. RES upregulates the expression of SIRT1 and MMP1, thus increasing the synthesis of the NP cell matrix $[50,51]$.

Notably, RES can also improve the degree of IDD by acting on the Akt-FoxO1-SIRT1 axis and activating the $\mathrm{mTOR} /$ caspase-3 signalling pathway $[52,53]$. Therefore, it has potential efficacy as treatment for IDD. At present, RES is presumed to control inflammation and oxidative stress, regulate autophagy, and reduce mechanical load damage. However, the cytotoxic and genotoxic effects of RES have not been elucidated, which has led to substantial challenges in terms of clinical applications. Further research is needed concerning the clinical applications of RES in IDD treatment, as well as the prevention of its side effects.

3.1.2. Coumarin. Coumarin is a natural phenolic compound from Solanaceae, Rutaceae, and Amburana cearensis $[54,55]$. It has anti-inflammatory and analgesic functions $[56,57]$. Coumarin scavenges active oxygen moieties, reducing oxidative stress; it also controls multiple signalling pathways [58, 59]. Su et al. [19] reported that isofraxidin, a coumarin compound, inhibits the NP inflammatory factors COX-2, iNOS, PGE2, TNF- $\alpha$, IL-6, MMP3, and MMP13; the expression of these factors is induced by IL- $1 \beta$. Isofraxidin also enhances the expression of collagen II and aggrecan through the NF- $\kappa \mathrm{B}$ signalling pathway. Acid-sensitive ion channel 3 is a $\mathrm{pH}$ sensor, mainly expressed in nociceptors [60]. He et al. [61] demonstrated that osthole, a natural coumarin derivative, reduces the expression of acid-sensitive ion channel 3 in the dorsal root ganglia and mitigates NPrelated mechanical pain. Sparstolonin B is also termed isocoumarin. Ge et al. [62] found that sparstolonin B alleviated inflammation, oxidative stress, and apoptosis of traumatised rat NP cells by inhibiting TLR4/NF- $\kappa \mathrm{B}$ signalling or activating PI3K/Akt signalling.

Although there have been relatively few studies on coumarin in IDD, we expect that coumarin has great potential in IDD research, based on its anti-inflammatory, antioxidant, and analgesic properties. Therefore, investigation of the molecular mechanism of coumarin is important for its future application in the treatment of IDD.

3.1.3. Curcumin and o-Vanillin. Curcumin (CUR) is a lipophilic polyphenolic substance, mainly isolated from the rhizome of the herbaceous plant turmeric [63]. It has antiinflammatory and antioxidant properties, promotes cell proliferation, and regulates senescence and autophagy signalling pathways $[64,65]$. CUR is actively used in the treatment of aging-related diseases, including cardiovascular diseases, atherosclerosis, neurodegenerative diseases, rheumatoid arthritis, osteoporosis, diabetes, hypertension, chronic kidney disease, and chronic inflammatory diseases $[66,67]$. In the context of IDD, Kang et al. [68] found that CUR can activate the AMPK/mTOR/ULK1 signalling pathway to enhance autophagy. This reduces ROS production; increases cytochrome c production; and protects NP cells from apoptosis, senescence, and ECM degradation caused by oxidative stress. o-Vanillin is the principal metabolite of curcumin. Cherif et al. [69] reported that curcumin and o-vanillin reduced the number of SA- $\beta$-gal-positive cells, thus slowing NP cell aging; lowered the expression levels of the inflammatory cytokines IL-6, IL-8, MMP3, and MMP13; and increased the levels of collagen II and aggrecan. These effects were mediated by the Nrf2 and NF- $\kappa$ B pathways. Cherif et al. [70] showed that o-vanillin upregulated CDK6, CDK2C, CDC25C, and other cell cycle genes, while it downregulated many common SASP factors including INF- $\gamma$ and IL-6; these changes led to slower human NP cell senescence. 
Nevertheless, there have been few studies on CUR in IDD, and its underlying mechanism is not fully understood. However, based on its abundance and unique biological activity, the potential molecular mechanism of CUR should be explored in the treatment of IDD to benefit patients with IDD.

3.1.4. Honokiol. Honokiol (HKL) is a natural bisphenol compound, mainly isolated from the leaves and bark of Magnolia plants [71]. It has anti-inflammatory, antioxidant, antiaging, and antiapoptosis properties, as well as the ability to regulate mitochondrial function and autophagy signalling pathways [72, 73]. Tang et al. [74] reported that HKL inhibits the activation of $N F-\kappa B$, which reduces the production of ROS in NP cells and the expression of inflammatory factors COX-2, iNOS, IL-1 $\beta$, and IL-6. It also regulates apoptosis and matrix metabolism in NP cells. Notably, SIRT3 is a member of the $\mathrm{NAD}^{+}$-dependent histone deacetylase family that regulates the activities of key oxidative phosphorylation enzymes through deacetylation, thereby controlling mitochondrial energy metabolism [75]. Wang et al. [76] reported that HKL upregulated the expression of SIRT3 in NP cells through the AMPK/PGC- $1 \alpha$ signalling pathway. Moreover, SIRT3 can downregulate the level of $\mathrm{O}^{2-}$, while upregulating the activity of SOD to maintain mitochondrial function and promote autophagy; these effects inhibit apoptosis and senescence in NP cells. Animal experiments have shown that HKL has a therapeutic effect on IDD. Chen et al. [77] used high-performance liquid chromatography to explore the distribution of $\mathrm{HKL}$ in rat intervertebral discs. In vitro analysis showed that HKL diffusion into the discs was concentration-dependent. HKL is of plant origin and thus exhibits low toxicity and few side effects; HKL slowed IDD progression when injected into animals. Therefore, HKL may be useful in the treatment of human IDD.

3.1.5. Salvianolic Acid. Salvianolic acid is the most abundant polyphenolic of Salvia miltiorrhiza; it exhibits anti-inflammatory, anticancer, antioxidant, and cardioprotective effects [78]. Dai et al. [79] found that salvianolic acid B activated the JAK2/STAT3 signalling pathway, reduced ROS and MDA production, and upregulated GSH and SOD2 production to maintain mitochondrial function in NP cells. Transformation of the mesenchymal stem cells (MSCs) of IDD patients has attracted considerable attention. Yan et al. [80] found that salvianolic acid B increased MSC collagen II and aggrecan production, indicating that the material promoted MSC differentiation into NP cells. Although there have been few relevant studies, we believe that salvianolic acid $B$ has great potential in terms of IDD treatment; the material promotes MSC differentiation into NP cells, which may greatly aid IDD patients.

3.1.6. Other Phenolics. Green tea polyphenols exhibit antioxidant and anti-inflammatory effects [81]. NOX activity is the principal source of extra-mitochondrial ROS. Song et al. [82] showed that tea polyphenols significantly inhibited the production of iNOS, NOX4, and ROS, as well as MMP3 expression, in NP cells treated with $\mathrm{H}_{2} \mathrm{O}_{2}$. Polyphenols increased the levels of collagen II, aggrecan, and SOX-9 by regulating the KEAP1/NRF2/ARE pathway. Pigallocatechin3-gallate is another natural polyphenol of green tea [83]. Tian et al. [84] reported that IDD was associated with upregulation of cGAS, STING, and NLRP3; moreover, pigallocatechin-3-gallate inhibited the cGAS/STING/ NLRP3 pathway and exerted antiapoptotic and anti-inflammatory effects. Gallic acid is a natural phenolic (a secondary metabolite of grape seeds, Syzygium fruticosum fruit, and other plants [85]). Gallic acid exerts strong antioxidant and anti-inflammatory effects [86]. Huang et al. [87] found that gallic acid inhibited TNF- $\alpha$-induced apoptosis and ADAMTS-4 production in NP cells by regulating $\mathrm{NF}-\kappa \mathrm{B}$ signalling. Sesamin is a natural polyphenol of sesame seeds that inhibits inflammation, proliferation, apoptosis, and other cellular actions [88]. Li et al. [89] found that sesamin reduced matrix catabolic enzyme expression (MMP1, MMP3, MMP13, ADAMTS-4, and ADAMTS-5) and the levels of the inflammatory factors IL- $1 \beta$, TNF- $\alpha$, iNOS, COX-2, and PGE2 in rat NP cells by inhibiting the MAPK pathway.

Polyphenols (also termed polyhydroxyphenols) are widespread in herbal medicines, tea, coffee, grains, and vegetables. They control inflammation and oxidative stress, while regulating autophagy; thus, they delay IDD progression and promote MSC differentiation into NP cells. The multiple pharmacological effects and multitargeting properties of natural polyphenols show great potential. However, further evidence of their utilities as IDD treatments is required (Table 1 and Figure 1).

\subsection{Flavonoids}

3.2.1. Icariin. Icariin (ICA) is a prenyl flavonoid and the main biologically active substance of herbal medicines [90]. It has antioxidant and anti-inflammatory functions, and it can maintain the integrity of mitochondrial membranes [91]. ICA can regulate the activities of telomeres, telomerase, and sirtuin proteins, as well as energy metabolism pathways and cell senescence [92]. Hua et al. [93] showed that ICA can inhibit the production of ROS and increase the expression of cytochrome $c$, which reduces oxidative stress damage to NP cells and inhibits apoptosis through the Nrf2 signalling pathway. Hua et al. [94] reported that ICA reduces the expression of COX-2 and iNOS in NP cells, inhibits the production of matrix-degrading enzymes, and enhances matrix anabolism by inhibiting the MAPK and NF- $\kappa \mathrm{B}$ signalling pathways. In an in vitro experiment, Deng et al. [95] demonstrated that ICA can reduce the levels of ROS, caspase-3, and Bax in NP cells; it can also inhibit cell apoptosis by activating the PI3K/Akt signalling pathway. ICA may improve the viability and function of cryopreserved human NP mesenchymal stem cells in addition to improving cell adhesion and maintaining mitochondrial function [92].

Although ICA has shown great potential in the treatment of IDD, its research in the context of IDD is relatively 
TABLE 1: Natural phenolics with pharmacological potential.

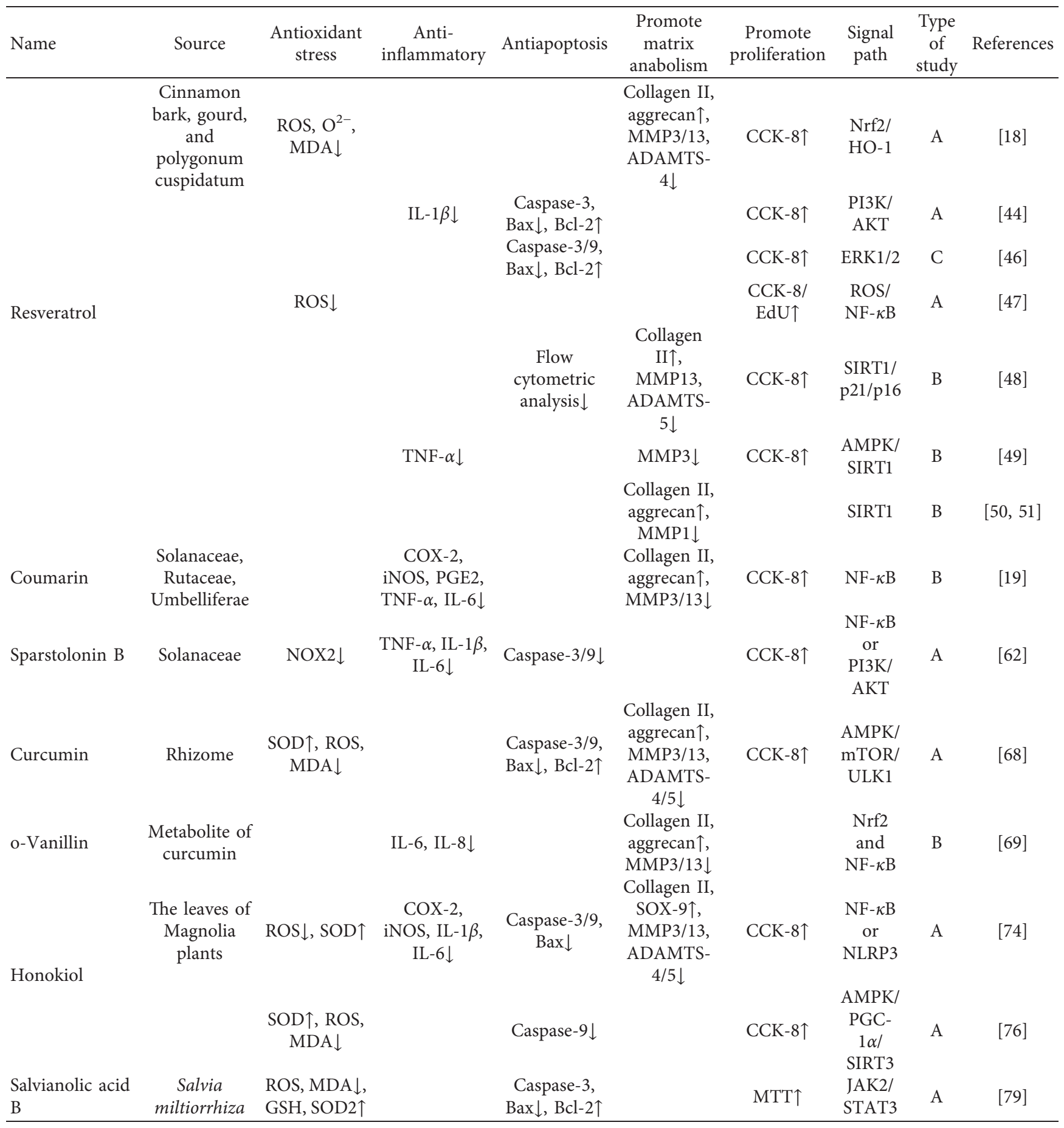


TABle 1: Continued.

\begin{tabular}{|c|c|c|c|c|c|c|c|c|c|}
\hline Name & Source & $\begin{array}{c}\text { Antioxidant } \\
\text { stress }\end{array}$ & $\begin{array}{c}\text { Anti- } \\
\text { inflammatory }\end{array}$ & Antiapoptosis & $\begin{array}{c}\text { Promote } \\
\text { matrix } \\
\text { anabolism }\end{array}$ & $\begin{array}{c}\text { Promote } \\
\text { proliferation }\end{array}$ & $\begin{array}{l}\text { Signal } \\
\text { path }\end{array}$ & $\begin{array}{l}\text { Type } \\
\text { of } \\
\text { study }\end{array}$ & References \\
\hline Tea polyphenols & Green tea & $\begin{array}{c}\text { NOX4, } \\
\text { ROS } \downarrow\end{array}$ & iNOS $\downarrow$ & & $\begin{array}{c}\text { Collagen II, } \\
\text { aggrecan } \\
\text { SOX-9 } \uparrow, \\
\text { MMP3 } \downarrow\end{array}$ & CCK-8 $\uparrow$ & $\begin{array}{c}\text { Keap1/ } \\
\text { Nrf2/ } \\
\text { ARE }\end{array}$ & B & {$[82]$} \\
\hline $\begin{array}{l}\text { Pigallocatechin- } \\
\text { 3-gallate }\end{array}$ & Green tea & & $\begin{array}{l}\text { IL- } 1 \beta \text {, TNF- } \alpha \text {, } \\
\text { IL- } 6, \text { IL-10 }\end{array}$ & $\begin{array}{l}\text { Caspase-3/9, } \\
\text { Bax } \downarrow, \text { Bcl- } 2 \uparrow\end{array}$ & & $\begin{array}{c}\text { CCK-8, } \\
\text { migration } \uparrow\end{array}$ & $\begin{array}{c}\text { cGAS/ } \\
\text { Sting/ } \\
\text { NLRP3 }\end{array}$ & B & {$[84]$} \\
\hline Gallic acid & $\begin{array}{l}\text { Grape seeds, } \\
\text { Chinese rose }\end{array}$ & & & $\begin{array}{c}\text { Flow } \\
\text { cytometric } \\
\text { analysis } \downarrow\end{array}$ & $\begin{array}{c}\text { ADAMTS- } \\
4 \downarrow\end{array}$ & CCK-8 $\uparrow$ & $N F-\kappa B$ & B & {$[87]$} \\
\hline Sesamin & Sesame seeds & & $\begin{array}{l}\text { IL- } 1 \beta \text {, TNF- } \alpha, \\
\text { iNOS, NO, } \\
\text { COX-2, } \\
\text { PGE2 } \downarrow\end{array}$ & & $\begin{array}{c}\text { Collagen } \\
\text { II } \uparrow, \text { MMP- } \\
\text { 1/3/13, } \\
\text { ADAMTS- } \\
4 / 5 \downarrow\end{array}$ & & MAPK & A & [89] \\
\hline
\end{tabular}

A: rat model of NP in vitro, in vivo. B: human model of NP in vitro. C: pig model of NP in vitro.<smiles>C=CCc1ccc(O)c(-c2ccc(O)c(CC=C)c2)c1</smiles>

(a)<smiles>COc1ccc(C=O)cc1O</smiles>

(e)

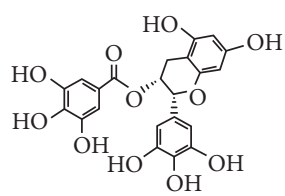

(i)<smiles>O=c1ccc2ccccc2o1</smiles>

(b)<smiles>C=CCc1ccc(O)c(-c2ccc(O)c(CC=C)c2)c1</smiles>

(f)<smiles>O=C(O)c1cc(O)c(O)c(O)c1</smiles>

(j)<smiles>CC(C)[C@@H]1CN(c2nc(Nc3cc(C(C)(C)C)[nH]n3)c3cc[nH]c3n2)CCN1</smiles>

(c)

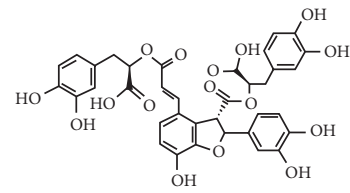

(g)

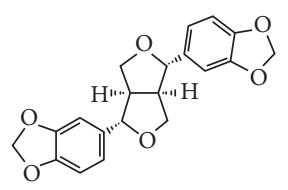

(k)

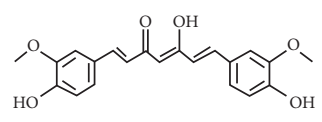

(d)

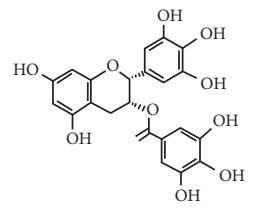

(h)

FIGURE 1: Chemical structures of phenolics with pharmacological potential: (a) resveratrol; (b) coumarin; (c) sparstolonin B; (d) curcumin; (e) o-vanillin; (f) honokiol; (g) salvianolic acid B; (h) tea polyphenol; (i) pigallocatechin-3-gallate; (j) gallic acid; (k) sesamin.

limited. In particular, its therapeutic effects and underlying molecular mechanisms require further analysis. Although ICA can slow cell senescence by regulating the activities of telomeres, telomerase, and sirtuin proteins, there is insufficient experimental evidence that ICA can slow the development of IDD. Therefore, further experimental verification is needed.

3.2.2. Naringin. Naringin (NRG) is a natural flavonoid compound, mainly extracted from citrus fruits [96]. It has anti-inflammatory, antioxidant, and antiapoptotic properties; it can regulate both autophagy and gluconeogenesis [97]. In addition, NRG can regulate molecular targets such as HMG-CoA reductase, NF- $\kappa \mathrm{B}, \mathrm{AMPK}, \mathrm{Nrf} 2$, and ROS [98]. NRG exhibits anti-bone resorption and antifat effects, enhances bone features, improves the bone microenvironment, and helps reconstruct bone structure [99]. Li et al. [100] showed that NRG can increase human NP cell viability and inhibit the expression of inflammatory cytokine TNF- $\alpha$, thereby enhancing the expression of collagen II and aggrecan. Zhang et al. [101] reported that, under TBHPmediated oxidative stress, NRG promotes autophagy in rat NP cells by activating the AMPK signalling pathway, which inhibits cell apoptosis and increases the production of collagen II and aggrecan. Gao et al. [102] found that NRG can substantially reduce the expression of inflammatory cytokines TNF- $\alpha$ and IL-6; it can improve the matrix 
anabolic ability of NP cells through the NF- $\kappa \mathrm{B}$ signalling pathway via IL-1 $\beta$-mediated induction. Nan et al. [103] demonstrated that NRG inhibits the level of ROS and increases mitochondrial membrane potential in rat NP-derived mesenchymal stem cells, which improves mitochondrial function and reduces the apoptosis of NP mesenchymal stem cells through the PI3K/Akt signalling pathway. Current research regarding the use of NRG in IDD is limited and its effectiveness has not been confirmed, although its antioxidant, antiapoptotic, anti-inflammatory, and autophagy-regulating effects can protect NP cells. Moreover, NRG can regulate gluconeogenesis. Further research is needed to support the use of NRG in clinical treatment of IDD, including qualitative and quantitative analyses of the mechanism underlying IDD and assessment of NRG efficacy in the treatment of IDD.

3.2.3. Genistein. Genistein (GES) is a natural isoflavone compound, mainly extracted from soybeans [104]. It has anti-inflammatory, antioxidant, and antiapoptotic properties, as well as the ability to improve mitochondrial function [105]. Heme oxygenase 1 and quino oxidase 1 play important roles in the Nrf2-mediated antioxidant defence system [106]. Wang et al. [107] studied the GES-mediated activation of the Nrf2 signalling pathway and found reduced levels of ROS in NP cells, which inhibited cell apoptosis and ECM catabolism. Animal experiments also confirmed this conclusion. Ge et al. [108] demonstrated that GES has protein tyrosine kinase inhibitory function, such that it blocks activation of the p38 MAPK pathway and reduces the expression of inflammatory factors TNF- $\alpha$ and IL- $1 \beta$ in rat $\mathrm{NP}$ cells, thereby promoting the expression of collagen II and aggrecan. The therapeutic effects of GES were confirmed in animal experiments. The current knowledge concerning GES is relatively limited; therefore, the abilities of GES to impact IDD through anti-inflammatory, antioxidant, and antiapoptotic properties require further research studies.

3.2.4. Wogonin. Wogonin (WG) is a natural flavonoid compound extracted from the root extract of Scutellaria baicalensis Georgi [109]. It has antioxidant and anti-inflammatory activities [110]. Fang et al. [111] reported that WG can inhibit the expression of inflammatory factors COX2 and iNOS, as well as the activities of MMP3, MMP13, and ADAMTS-4. Moreover, it can promote the expression of collagen II and aggrecan, which are regulated by the Nrf2/ ARE signal axis. Although there has been minimal research concerning WG, the Nrf2/ARE signalling pathway is a wellknown pathway involved in IDD molecular signalling. Thus, WG may have potential treatment applications in IDD, but supporting experimental data are needed.

3.2.5. Luteoloside. Luteoloside (Lut) is a natural flavonoid of honeysuckle, lettuce, silver flower, and salvia [112]. Lut exerts antioxidant, anti-inflammatory, antiautophagy, and analgesic effects [113]. Lin et al. [114] demonstrated that Lut inhibited NF- $\kappa \mathrm{B}$ signalling and the expression of the inflammatory factors iNOS, COX-2, PGE2, NO, TNF- $\alpha$, and IL-6 in rat NP cells. Lut also regulated the expression of key molecules involved in matrix degradation (MMP13 and ADAMTS-5), thereby inhibiting apoptosis and promoting the production of collagen II and aggrecan. Animal experiments have confirmed the therapeutic effects of Lut on IDD. Although few human studies have appeared, the antiinflammatory and antioxidant properties suggest that further research is desirable.

3.2.6. Quercetin. Quercetin is a naturally occurring phenolic of vegetables, fruits, and Gynura plants that may protect against a number of diseases of aging including osteoporosis and heart disease $[115,116]$. Wang et al. [117] showed that quercetin activated the SIRT1 autophagy signalling pathway and reduced TBHP-induced ROS production, thereby inhibiting NP cell apoptosis and matrix catabolism. Animal experiments confirmed the therapeutic effects of quercetin on IDD. Shao et al. [118] reported that quercetin may bind to the KEAP1-NRF2 complex to inhibit the NF- $\kappa \mathrm{B}$ pathway, thus reducing the IL- $1 \beta$-mediated expression of IL- 6 , IL-8, MMP13, and MMP3; this alleviates NP cell senescence. There is minimal evidence that quercetin can slow IDD development; more work is needed.

3.2.7. Other Flavonoids. Baicalein is a natural flavonoid from the roots of Scutellaria baicalensis and Scutellaria lateriflora, which exhibits antioxidant and anti-inflammatory activities [119]. Jin et al. [120] found that baicalein inhibited IL- $1 \beta$ production by NP cells and increased NP ECM synthesis by regulating NF- $\kappa$ B and MAPK signalling. Apigenin is a flavonoid of Asteraceae [121]. Ding and Li [122] found that apigenin ameliorated inflammatory factor expression and inhibited cell matrix metalloprotein synthesis by acting on the TNF- $\alpha$ signalling pathway. Kaempferol is a flavonoid of Ginkgo and Moringa that exhibits antiaging, antioxidant, anti-inflammatory, and antiosteoporosis effects [123]. Bone marrow-derived mesenchymal stem cells represent a potential autologous stem cell source for NP regeneration. Zhu et al. [124] found that, by activating NF- $\kappa \mathrm{B}$, kaempferol reduced the levels of the proinflammatory cytokine IL- 6 in bone marrow-derived mesenchymal stem cells; it also enhanced SOX-9, collagen II, and aggrecan production by those cells.

Flavonoids are widespread in fruits, vegetables, herbs, and other plant foods. The activities of hydroxyphenolic flavonoids are structure-dependent. Natural flavonoids exert anti-inflammatory and antioxidant effects; they slow cell senescence by regulating senescence-associated enzymes. Such products may be useful in the treatment of IDD, but more data are needed (Table 2 and Figure 2).

\subsection{Alkaloids}

3.3.1. Berberine. Berberine (BBR) is a quaternary ammonium alkaloid isolated from the traditional Chinese medicine Rhizoma coptidis, which has antioxidant, anti- 
TABLE 2: Natural flavonoids with pharmacological potential.

\begin{tabular}{|c|c|c|c|c|c|c|c|c|c|}
\hline Name & Source & $\begin{array}{c}\text { Antioxidant } \\
\text { stress }\end{array}$ & $\begin{array}{c}\text { Anti- } \\
\text { inflammatory }\end{array}$ & Antiapoptosis & $\begin{array}{c}\text { Promote } \\
\text { matrix } \\
\text { anabolism }\end{array}$ & $\begin{array}{c}\text { Promote } \\
\text { proliferation }\end{array}$ & $\begin{array}{l}\text { Signal } \\
\text { path }\end{array}$ & $\begin{array}{l}\text { Type } \\
\text { of } \\
\text { study }\end{array}$ & References \\
\hline \multirow{3}{*}{ Icariin } & Epidemic & ROS $\downarrow$ & & $\begin{array}{c}\text { Caspase-3, } \\
\text { Bax } \downarrow \text {, Bcl-2 } \uparrow, \\
\text { TUNEL } \downarrow\end{array}$ & & CCK- $8 \uparrow$ & Nrf2 & B & [93] \\
\hline & & & $\begin{array}{c}\text { COX-2, iNOS, } \\
\text { PGE2 } \downarrow\end{array}$ & & $\begin{array}{c}\text { Collagen II, } \\
\text { aggrecan } \uparrow, \\
\text { MMP3, } \\
\text { ADAMTS- } \\
4 \downarrow\end{array}$ & CCK- $8 \uparrow$ & $\begin{array}{l}\text { MAPK } \\
\text { and NF- } \\
\kappa \mathrm{B}\end{array}$ & B & {$[94]$} \\
\hline & & $\mathrm{ROS} \downarrow$ & & $\begin{array}{c}\text { Caspase-3, } \\
\operatorname{Bax} \downarrow, \mathrm{Bcl}-2 \uparrow\end{array}$ & & 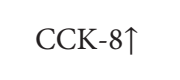 & $\begin{array}{l}\text { PI3K/ } \\
\mathrm{AKT}\end{array}$ & A & [95] \\
\hline \multirow{5}{*}{ Naringin } & Citrus fruits & & TNF- $\alpha \downarrow$ & & $\begin{array}{c}\text { Collagen II, } \\
\text { aggrecan } \uparrow, \\
\text { MMP3 }\end{array}$ & MTT $\uparrow$ & & B & {$[100]$} \\
\hline & & & & $\begin{array}{c}\text { Caspase-3, } \\
\text { Bax } \downarrow, \text { Bcl- } 2 \uparrow\end{array}$ & $\begin{array}{c}\text { Collagen II } \uparrow, \\
\text { MMP13 }\end{array}$ & 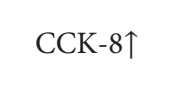 & AMPK & A & [101] \\
\hline & & & & & $\begin{array}{l}\text { Collagen II, } \\
\text { aggrecan } \uparrow \text {, }\end{array}$ & & & & \\
\hline & & & TNF- $\alpha$, IL- $6 \downarrow$ & & $\begin{array}{c}\text { MMP3/13, } \\
\text { ADAMTS- } \\
4 / 5 \downarrow\end{array}$ & & $N F-\kappa B$ & B & [102] \\
\hline & & ROS $\downarrow$ & & $\begin{array}{c}\text { Caspase-3, } \\
\text { Bax } \downarrow \text {, Bcl- } 2 \uparrow\end{array}$ & & 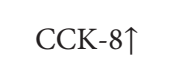 & PI3K/Akt & A & [103] \\
\hline \multirow{2}{*}{ Genistein } & Soybeans & ROS $\downarrow$ & & $\begin{array}{c}\text { Caspase-3, } \\
\text { Bax } \downarrow, \text { Bcl- } 2 \uparrow\end{array}$ & $\begin{array}{c}\text { Collagen II } \uparrow, \\
\text { ADAMTS-5, } \\
\text { MMP13 }\end{array}$ & CCK-8 $\uparrow$ & Nrf2 & A & [107] \\
\hline & & & $\begin{array}{c}\text { TNF- } \alpha, \text { IL- } \\
1 \beta \downarrow\end{array}$ & & $\begin{array}{c}\text { Collagen II, } \\
\text { aggrecan } \uparrow \text {, } \\
\text { MMP3 }\end{array}$ & CCK-8 $\uparrow$ & $\begin{array}{c}\text { p38 } \\
\text { MAPK }\end{array}$ & A & [108] \\
\hline Wogonin & $\begin{array}{l}\text { Scutellaria } \\
\text { baicalensis } \\
\text { Georgi }\end{array}$ & & $\begin{array}{l}\text { COX-2, } \\
\text { iNOS } \downarrow\end{array}$ & & $\begin{array}{c}\text { Collagen II } \uparrow \text {, } \\
\text { MMP3/13, } \\
\text { ADAMTS- } \\
4 \downarrow\end{array}$ & $\begin{array}{c}\text { CCK-8/ } \\
\text { EdU个 }\end{array}$ & Nrf2/ARE & A & [111] \\
\hline Luteoloside & $\begin{array}{l}\text { Honeysuckle, } \\
\text { lettuce, silver } \\
\text { flower }\end{array}$ & & $\begin{array}{l}\text { TNF- } \alpha, \text { COX- } \\
\text { 2, iNOS, } \\
\text { PGE2 } \downarrow\end{array}$ & $\begin{array}{c}\text { Caspase-3, } \\
\text { Bax } \downarrow, \text { Bcl- } 2 \uparrow\end{array}$ & $\begin{array}{c}\text { Collagen II, } \\
\text { aggrecan } \uparrow \text {, } \\
\text { MMP13, } \\
\text { ADAMTS- } \\
5 \downarrow\end{array}$ & & $N F-\kappa B$ & A & [114] \\
\hline \multirow{2}{*}{ Quercetin } & $\begin{array}{l}\text { Vegetables, } \\
\text { fruits, and teas }\end{array}$ & ROS $\downarrow$ & & Caspase-3\ & $\begin{array}{c}\text { Aggrecan } \uparrow, \\
\text { MMP13】 }\end{array}$ & CCK-8 $\uparrow$ & $\begin{array}{c}\text { SIRT1- } \\
\text { autophagy }\end{array}$ & $\mathrm{C}$ & [117] \\
\hline & & & IL-6, IL-8\ & & $\begin{array}{l}\text { MMP13, } \\
\text { MMP3 }\end{array}$ & EDU $\uparrow$ & $\begin{array}{c}\text { Nrf2/NF- } \\
\kappa \mathrm{B}\end{array}$ & $\mathrm{C}$ & [118] \\
\hline Baicalein & $\begin{array}{c}\text { Scutellaria } \\
\text { baicalensis and } \\
\text { Scutellaria } \\
\text { lateriflora }\end{array}$ & & $\begin{array}{l}\text { iNOS, COX-2, } \\
\text { TNF- } \alpha \text {, IL-6, } \\
\text { PGE2, NO } \downarrow\end{array}$ & & $\begin{array}{c}\text { Collagen II, } \\
\text { aggrecan } \uparrow \text {, } \\
\text { MMP13, } \\
\text { ADAMTS- } \\
5 \downarrow\end{array}$ & CCK-8 $\uparrow$ & $\begin{array}{c}\mathrm{NF}-\kappa \mathrm{B} \\
\text { and } \\
\mathrm{MAPK}\end{array}$ & A & [120] \\
\hline Apigenin & Asteraceae & & $\begin{array}{c}\text { COX-2, IL-2, } \\
\text { IL-6, IL- } 8, \text { IL- } \\
17, \text { IFN- } \gamma \text {, IL- } \\
1 \beta \downarrow\end{array}$ & & $\begin{array}{c}\text { Aggrecan } \uparrow, \\
\text { MMP1/3/9, } \\
\text { ADAMTS- } \\
4 / 5 \downarrow\end{array}$ & CCK-8 $\uparrow$ & & A & [122] \\
\hline Kaempferol & $\begin{array}{c}\text { Ginkgo and } \\
\text { Moringa }\end{array}$ & & IL-6」 & & 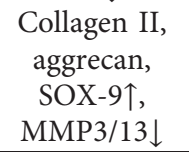 & CCK-8 $\uparrow$ & $\mathrm{NF}-\kappa \mathrm{B}$ & $\mathrm{D}$ & {$[124]$} \\
\hline
\end{tabular}

A: rat model of NP in vitro, in vivo. B: human model of NP in vitro. C: human model of NP in vitro and rat model of IDD in vivo. D: rat model of BMSCs in vitro. 


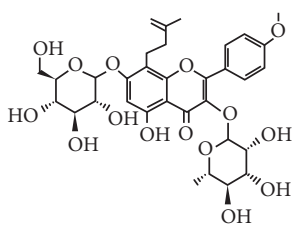

(a)

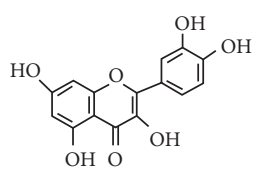

(f)

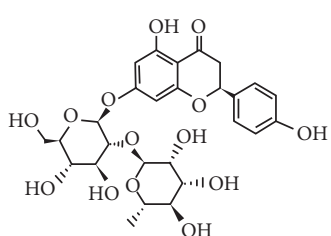

(b)

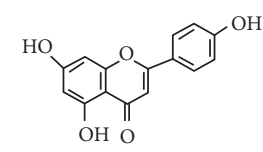

(g)<smiles>O=c1c(-c2ccc(O)cc2)coc2cc(O)cc(O)c12</smiles>

(c)

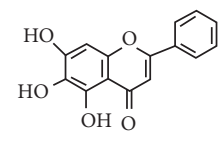

(h)

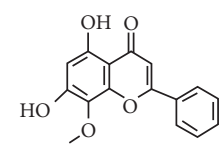

(O)

(d)

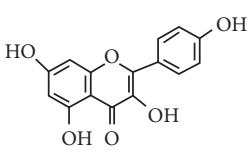

(i)

FIGURe 2: Chemical structures of phenolics with pharmacological potential: (a) icariin; (b) naringin; (c) genistein; (d) wogonin; (e) luteoloside; (f) quercetin; (g) baicalein; (h) apigenin; (i) kaempferol.

inflammatory, and antiapoptotic effects [125]. BBR and its derivatives, as well as associated pharmaceutical preparations, have good effects on cancer, obesity, diabetes, inflammation, atherosclerosis, Alzheimer's disease, rheumatoid arthritis, and cardiovascular diseases [126]. Lu et al. [127] reported that BBR inhibits the activation of NF$\kappa \mathrm{B}$ signalling and the expression of caspase-3, MMP3/13, and ADAMTS-4/5, thereby exerting antiapoptotic and ECM catabolism effects. Luo et al. [128] demonstrated that BBR reduced the production of ROS in NP cells and inhibited cell apoptosis by regulating both endoplasmic reticulum stress and autophagy through the IRE1/JNK pathway. Chen et al. [129] studied the therapeutic effect of BBR in the treatment of IDD, which may reduce NP cell apoptosis and inhibit ECM catabolism by activating autophagy.

3.3.2. Oxymatrine. Oxymatrine is a quinazine alkaloid from Sophora flavescens that reduces inflammation, oxidative stress, and apoptosis [130]. Wei et al. [131] reported that, by regulating NF- $\kappa \mathrm{B}$ signalling, oxymatrine reduced MMP levels in NP cells; it also reduced IL- $1 \beta$-induced apoptosis of those cells. Furthermore, oxymatrine increased collagen II and aggrecan expression in NP cells. Animal experiments confirmed these protective effects. Liposomes are biocompatible nanocarriers used to deliver various drugs. Wang et al. [132] found that such delivery enhanced drug distributions in targeted areas. Oxymatrine-liposomes enhanced drug accumulation in intervertebral discs, while reducing NP cell apoptosis and ECM degeneration.

3.3.3. Other Alkaloids. Piperine is an alkaloid of Piper longum L. [133] that exhibits antioxidant, antisenescence, and immunomodulatory effects [134]. Li et al. [135] demonstrated that piperine inhibited LPS-mediated JNK phosphorylation and NF- $\kappa \mathrm{B}$ activation, thus reducing the levels of the inflammatory factors IL- $1 \beta$, TNF- $\alpha$, IL- 6 , and iNOS; piperine also enhanced matrix anabolism in NP cells.

Our current knowledge of alkaloids is relatively limited. Determination of the capacities of alkaloids to inhibit IDD requires further research; the liposomal combination approach may offer a new path towards IDD treatment (Table 3 and Figure 3).

\subsection{Terpenoids}

3.4.1. Andrographolide. Andrographolide is a natural terpenoid of the Acanthaceae family, commonly termed "King of the bitters" or "Kalmegh" [136], that exerts antioxidant, anti-inflammatory, and antiapoptotic effects [137]. Liu et al. [138] showed that andrographolide inhibited production of the inflammatory factors COX-2 and PGE2, while reversing MMP3, MMP13, ADAMTS-4, and ADAMTS-5 overexpression, by inhibiting NF- $\kappa$ B activation. Zhang et al. [139] reported that andrographolide inhibited the expression of several matrix metalloproteinases (MMP3, MMP9, and MMP13), as well as apoptosis, by controlling NF- $\kappa$ B signalling.

3.4.2. Other Terpenoids. Glycyrrhizic acid is a triterpene from liquorice roots and rhizomes that exerts anti-inflammatory and antioxidant effects [140]. Liu et al. [141] found that glycyrrhizic acid inhibited the expression of the inflammatory factors TNF- $\alpha$, IL-6, IL-8, and iNOS, as well as apoptosis, by reducing p38/p-JNK signalling; thus, it prevented NP cell degradation. CDDO and its derivatives are terpenoids derived from oleanolic acid that exert anti-inflammatory, anticancer, and antioxidant effects. Zhang et al. [142] found that Nrf2 activation was essential for the overexpression of HO-1 induced by CDDO-ethyl amide (EA); this protected NP cells from the oxidative stress induced by high glucose. Cannabinoids are natural terpenoids from hemp [143] that exhibit anti-inflammatory and antimicrobial effects [144]. Cannabidiol was injected into rat intervertebral discs injured via needle puncture. MRI and histological analysis revealed that cannabidiol significantly reduced intervertebral disc damage [145].

The anti-inflammatory and antioxidant terpenoids enhance the repair cascade at sites of intervertebral disc injury. They are expected to restore NP cell function. Future 
TABLE 3: Natural alkaloids with pharmacological potential.

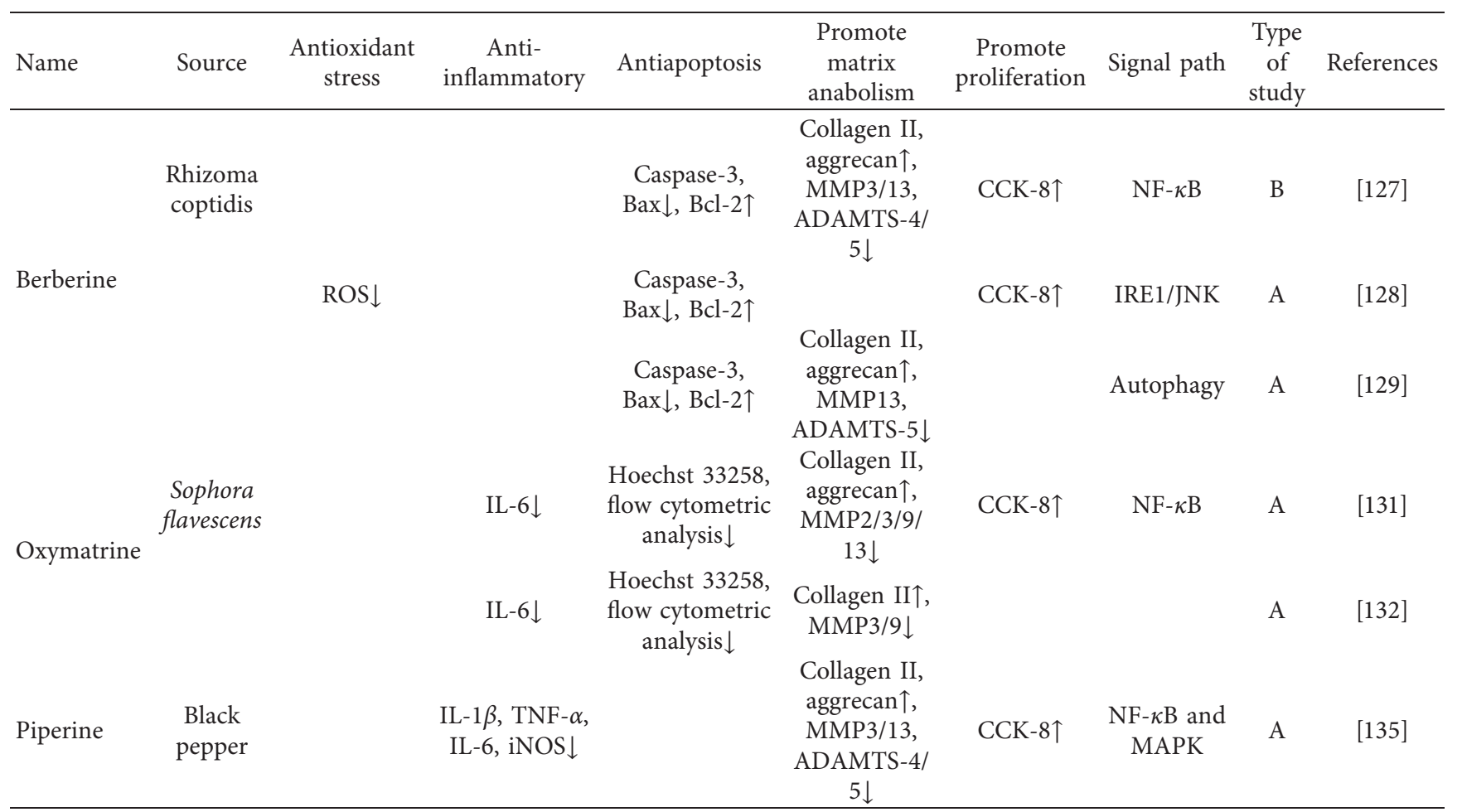

A: rat model of NP in vitro, in vivo. B: human model of NP in vitro.

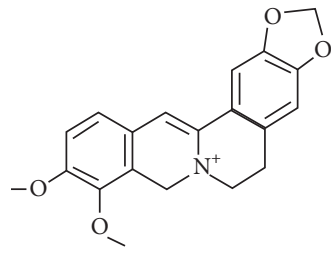

(a)

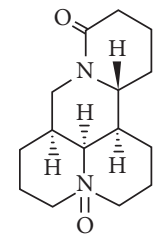

(b)

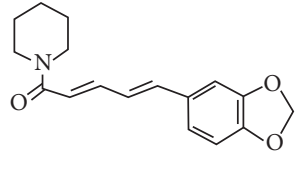

(c)

FIGURE 3: Chemical structures of alkaloids with pharmacological potential: (a) berberine; (b) oxymatrine; (c) piperine.

analyses of the molecular mechanisms involved and consideration of appropriate administration routes are important (Table 4 and Figure 4).

\subsection{Saponins and Quinones}

3.5.1. Ginsenosides. Ginsenosides (GSs) are saponins, also termed triterpene saponins, mainly found in medicinal materials from the ginseng genus [146]. According to the position and quantity of the sugar moiety in ginseng-derived sugar, GSs are divided into three types: protopanaxadiol, protopanaxatriol, and oleanolic acid, all of which have antiinflammatory, antioxidant, and antiapoptotic effects [147]. $\mathrm{Yu}$ et al. [148] showed that the GSs Rg1 regulates Wnt/ $\beta$-catenin signalling, promotes the proliferation of rat NP cells and the production of collagen II and aggrecan, and reduces cell apoptosis. Chen et al. [149] reported that the GSs $\mathrm{Rg} 3$ inhibits the NF- $\kappa \mathrm{B}$ signalling pathway and reduces the production of ROS in NP cells, thereby promoting cell proliferation and ECM anabolism, while reducing apoptosis.
3.5.2. Plumbagin. Plumbagin is a quinone from the root of the medicinal herb "graphite" that exhibits anti-inflammatory and antioxidant effects [150]. Chu et al. [151] found that plumbagin reduced NP cell oxidative stress and inflammation induced by $\mathrm{H}_{2} \mathrm{O}_{2}$ by modulating NF- $\kappa \mathrm{B}$ and $\mathrm{Nrf} 2$ signalling, reducing apoptosis.

Although saponins and quinones may be useful in the treatment of IDD, their effects have not been fully explored. More work is needed (Table 5 and Figure 5).

\section{Mechanisms of Action of Natural Products Treating IDD}

4.1. Natural Products Inhibit Inflammation. Inflammation is a complex physiological response to cellular damage, infection, and tissue injury [152]. As intervertebral disc cells degenerate, the corresponding increased levels of secreted proinflammatory cytokines trigger IDD progression. TNF- $\alpha$, IL-6, IL-8, IL-4, and PGE2 trigger the inflammatory cascade; they promote NP ECM degradation, cell senescence, and 


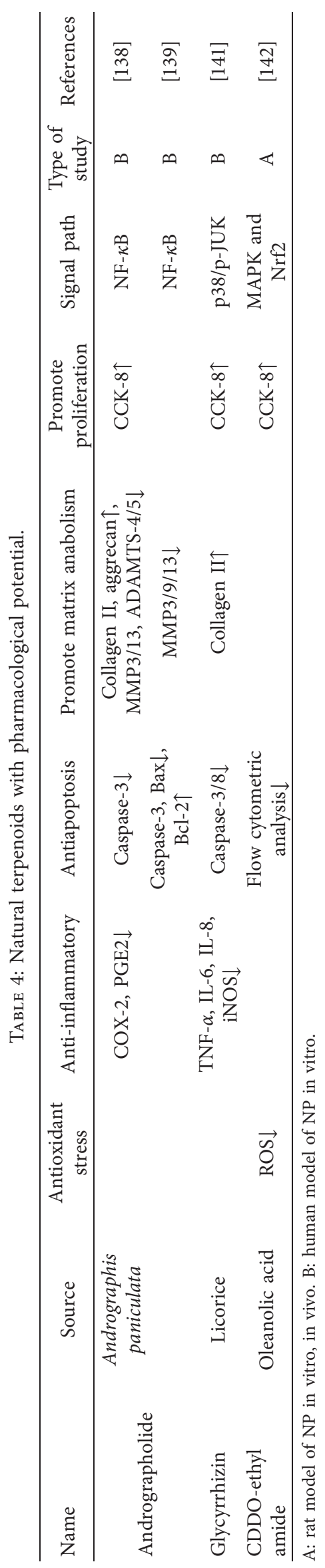




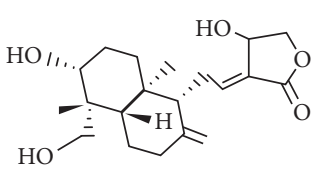

(a)

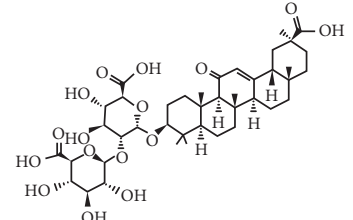

(b)

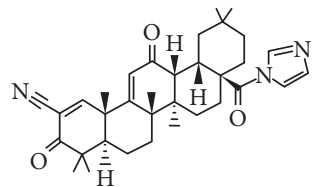

(c)

FIgURE 4: Chemical structures of terpenoids with pharmacological potential: (a) andrographolide; (b) glycyrrhizin; (c) CDDO-EA.

Table 5: Natural saponins and quinones with pharmacological potential.

\begin{tabular}{lcccccccc}
\hline Name & Source & $\begin{array}{c}\text { Antioxidant } \\
\text { stress }\end{array}$ & $\begin{array}{c}\text { Anti- } \\
\text { inflammatory }\end{array}$ & Antiapoptosis & $\begin{array}{c}\text { Promote } \\
\text { matrix } \\
\text { anabolism }\end{array}$ & $\begin{array}{c}\text { Promote } \\
\text { proliferation }\end{array}$ & $\begin{array}{c}\text { Signal } \\
\text { path }\end{array}$ & $\begin{array}{c}\text { Type } \\
\text { of } \\
\text { study }\end{array}$ \\
References \\
Ginseng \\
genus
\end{tabular}

A: rat model of NP in vitro. B: human model of NP in vitro.

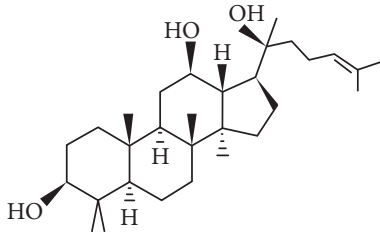

(a)<smiles>CC1=CC(=O)c2c(O)cccc2C1=O</smiles>

(b)

FIGURE 5: Chemical structures of saponins and quinones with pharmacological potential: (a) The saponins of ginsenosides; (b) the quinones of plumbagin.

apoptosis [34]. Inflammation is a critical component of IDD. Natural products reduce the expression of IL-6, IL-8, COX2 , iNOS, and PGE2, thereby delaying IDD. Natural products affect different signalling pathways alone or in concert (Figure 6).

4.2. Natural Products Inhibit Oxidative Stress. Oxidative stress is an imbalance between the levels of pro-oxidants and antioxidants; excess ROS cause cellular damage [153]. ROS are produced through the normal metabolism of mitochondria and peroxisomes, as well as by various cytoplasmic enzymes that either promote cell survival and tissue renewal or inhibit the expression of cell survival genes [154]. As IDD develops, ROS production by intervertebral discs increases [155]. Excessive ROS production disturbs intracellular redox homeostasis and triggers NP cell apoptosis and senescence, as well as ECM degradation. Therefore, oxidative stress is also important in terms of IDD. Natural products reduce oxidative stress and maintain NP cell redox homeostasis (Figure 7).
4.3. Natural Products Inhibit Apoptosis and ECM Degradation. Apoptosis is a form of programmed death controlled by genes that maintain homeostasis. Abnormal NP cell apoptosis plays an important role in IDD. Hoechst 33258 flow cytometric analysis is used to detect apoptosis. Natural products reduce the expression of the apoptotic proteins caspase-3, caspase-9, Bax, and Bcl-2. Collagen II and aggrecan are the principal components of the ECM, which structurally and biochemically supports intervertebral disc cells [156]. ECM degradation is a principal characteristic of IDD; MMPs and ADAMTS are the principal catabolic enzymes. Therefore, inhibition of apoptosis and matrix catabolism may slow IDD progression (Figure 8).

Inflammation and oxidative stress are important in terms of IDD development; the molecular mechanisms differ. NP cell apoptosis and ECM degeneration accelerate IDD; natural products inhibit NP cell apoptosis and ECM degeneration. Natural products affect NP cell apoptosis and senescence, as well as matrix anabolism, by inhibiting inflammation- and oxidative stress-related signalling, thus 


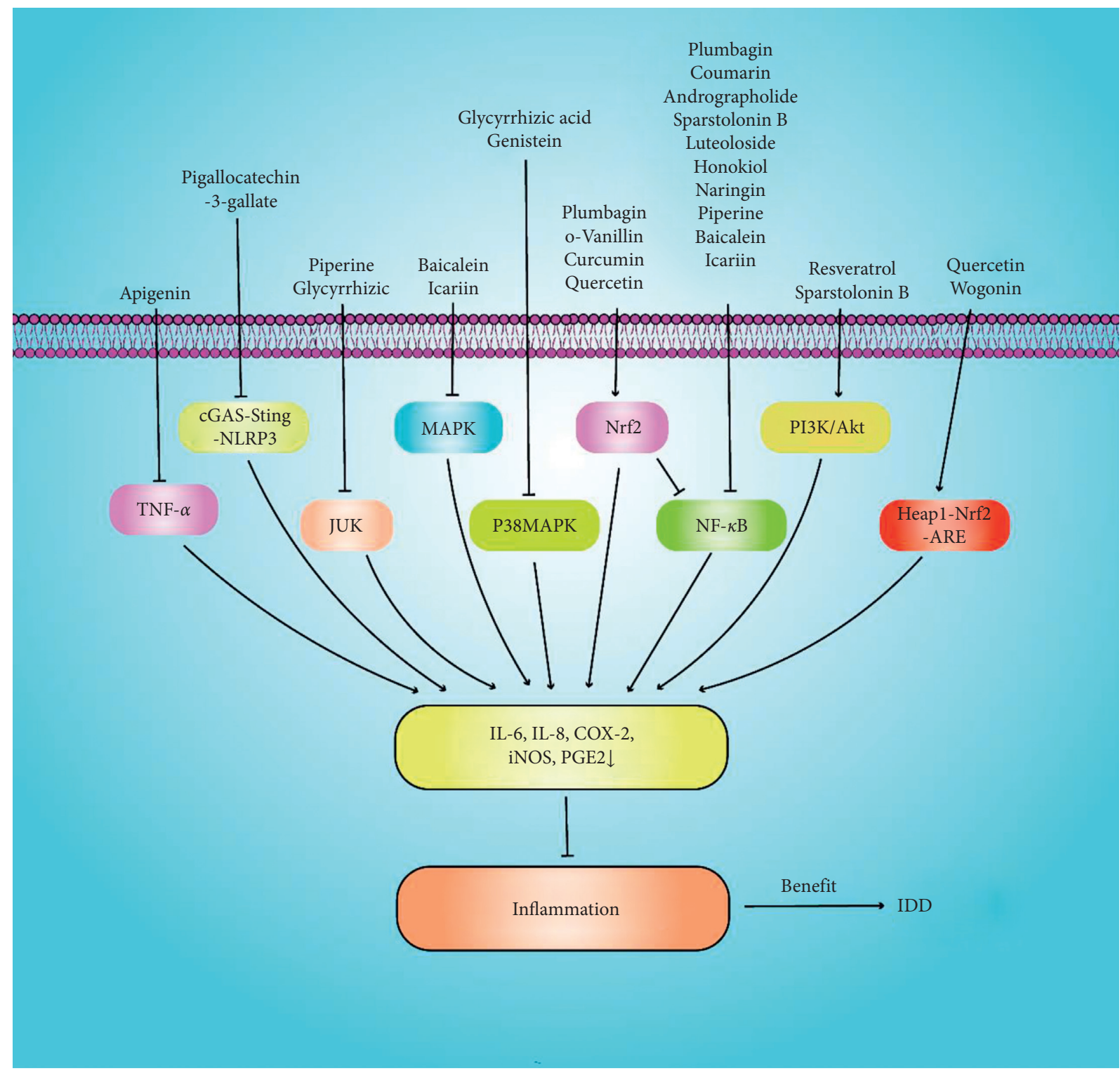

FIGURE 6: Natural products inhibit inflammation-related signalling pathways and reduce the expression of the inflammatory cytokines IL-6, IL-8, COX-2, iNOS, and PGE2, thereby delaying intervertebral disc degeneration.

delaying IDD progression. Other factors (mitochondrial dysfunction and DNA damage) are also involved. More basic research is needed.

\section{Clinical Applications}

The drugs used to treat IDD relieve symptoms; they do not reverse IDD. Intervertebral disc tissue lacks blood vessels and nerves. Intervertebral disc structure and function are maintained by the osmotic effect of the CEP, reducing the efficacies of oral and intravenous drugs. There is an urgent need to develop effective drugs and reasonable routes of intervertebral disc administration. Nanoparticles have large surface areas and pore volumes, which allow them to effectively load drugs [157]. A combination of a nanomaterial and oxymatrine increased drug anti-IDD activity, suggesting a novel route of drug administration [132]. Natural products are prime sources of drug development [158]. Currently, most of the work on natural products for IDD has focused on preclinical nature. Although the natural product has not been studied in clinical practice, its powerful pharmacological activity has great potential in the treatment of IDD. The Sprague Dawley rat IDD model establishes an intervertebral disc injury in a tail vertebra via needle puncture. Natural products were given by gavage, intraperitoneal injection, and local injection. We summarise the progress of preclinical research in Table 6. 


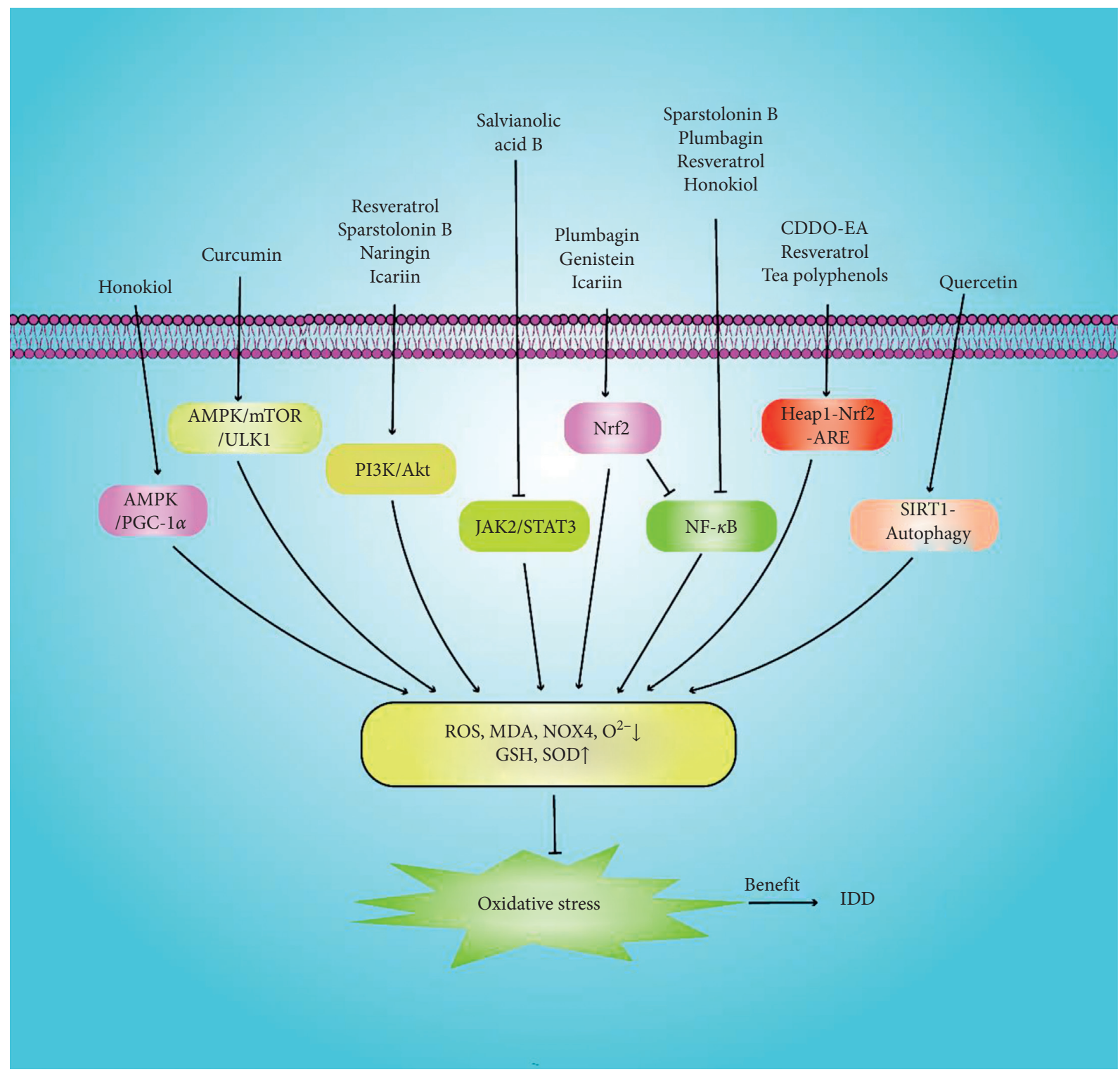

Figure 7: Natural products increase GSH and SOD expression and decrease those of ROS, MDA, NOX4, and $\mathrm{O}^{2-}$ by inhibiting the oxidative stress-related signalling pathways involved in intervertebral disc degeneration. 


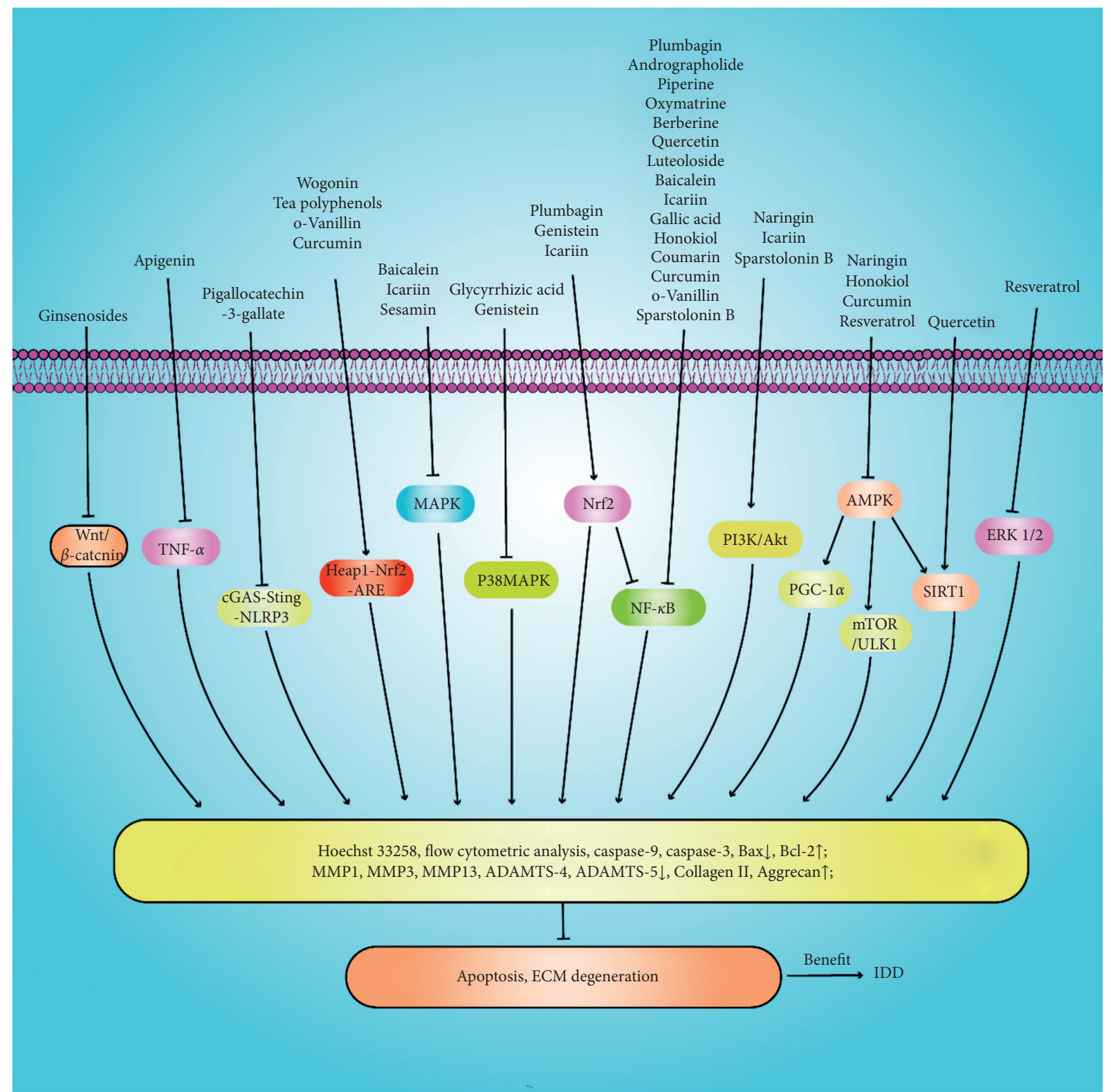

FIGURE 8: Natural products inhibit apoptosis and ECM degeneration through different mechanisms to prevent intervertebral disc degeneration. 
TABLE 6: Natural products used for preclinical research.

\begin{tabular}{|c|c|c|c|c|c|}
\hline Name & $\begin{array}{l}\text { Intervention } \\
\text { approach }\end{array}$ & Drug dosage & $\begin{array}{c}\text { Duration } \\
\text { (weeks) }\end{array}$ & $\begin{array}{l}\text { Summary of main findings (compared with IDD } \\
\text { group) }\end{array}$ & References \\
\hline Resveratrol & $\begin{array}{c}\text { Intragastric } \\
\text { administration }\end{array}$ & $50 \mathrm{mg} / \mathrm{kg} / \mathrm{d}$ & 4 & $\begin{array}{l}\text { Decrease Pfirrmann MRI grade; Alcian blue: } \\
\text { increase the content of ECM; SA- } \beta \text {-Gal staining: } \\
\text { the number of positive cells decreases }\end{array}$ & {$[18]$} \\
\hline Curcumin & $\begin{array}{l}\text { Injected } \\
\text { intraperitoneally }\end{array}$ & $100 \mathrm{mg} / \mathrm{kg} / \mathrm{d}$ & 4 & $\begin{array}{c}\text { Decrease Pfirrmann MRI grade; HE: IVD } \\
\text { morphology improvement; } \\
\text { immunohistochemistry: collagen II and } \\
\text { aggrecan content increased }\end{array}$ & {$[68]$} \\
\hline \multirow[b]{2}{*}{ Honokiol } & $\begin{array}{l}\text { Injected } \\
\text { intraperitoneally }\end{array}$ & $30 \mathrm{mg} / \mathrm{kg} / \mathrm{d}$ & 4 & $\begin{array}{l}\text { Decrease Pfirrmann MRI grade; HE and Alcian } \\
\text { blue: IVD morphology improved; } \\
\text { immunohistochemistry: MMP13 and } \\
\text { ADAMATS-5 expression decreased }\end{array}$ & {$[74]$} \\
\hline & $\begin{array}{c}\text { Intragastric } \\
\text { administration }\end{array}$ & $40 \mathrm{mg} / \mathrm{kg} / \mathrm{d}$ & 4 & $\begin{array}{c}\text { Decrease Pfirrmann MRI grade; HE: IVD } \\
\text { morphology improvement; } \\
\text { immunofluorescence: upregulation of SIRT3 } \\
\text { expression }\end{array}$ & {$[76]$} \\
\hline $\begin{array}{l}\text { Salvianolic } \\
\text { acid B }\end{array}$ & $\begin{array}{c}\text { Intragastric } \\
\text { administration }\end{array}$ & $20 \mathrm{mg} / \mathrm{kg} / \mathrm{d}$ & 6 & $\begin{array}{c}\text { Decrease Pfirrmann MRI grade; HE, safranin-O } \\
\text { fast green, and Alcian blue: IVD shape } \\
\text { improvement }\end{array}$ & [79] \\
\hline $\begin{array}{l}\text { Tea } \\
\text { polyphenol }\end{array}$ & Local injection & $100 \mu \mathrm{M} /$ week & 4 & $\begin{array}{l}\text { Decrease Pfirrmann MRI grade; HE, safranin-O } \\
\text { fast green, and Alcian blue: IVD shape } \\
\text { improvement; immunohistochemistry: collagen } \\
\text { II and aggrecan content increased }\end{array}$ & {$[82]$} \\
\hline Icariin & $\begin{array}{l}\text { Injected } \\
\text { intraperitoneally }\end{array}$ & $30 \mathrm{mg} / \mathrm{kg} / \mathrm{d}$ & 8 & $\begin{array}{l}\text { Decrease the Pfirrmann MRI grade; increase the } \\
\text { height of the IVD; immunohistochemistry: } \\
\text { aggrecan content increased; TUNEL: decreased } \\
\text { rate of positive cells }\end{array}$ & {$[93]$} \\
\hline Naringin & $\begin{array}{l}\text { Injected } \\
\text { intraperitoneally }\end{array}$ & $80 \mathrm{mg} / \mathrm{kg} / \mathrm{d}$ & 4 and 12 & $\begin{array}{l}\text { Decrease Pfirrmann MRI grade; HE: IVD } \\
\text { morphology improved }\end{array}$ & {$[101]$} \\
\hline \multirow[b]{2}{*}{ Genistein } & $\begin{array}{c}\text { Intragastric } \\
\text { administration }\end{array}$ & $100 \mathrm{mg} / \mathrm{kg} / \mathrm{d}$ & 4 & $\begin{array}{c}\text { X-ray: increased intervertebral space height; } \\
\text { HE: improved IVD morphology; } \\
\text { Immunofluorescence: upregulated expression } \\
\text { of Nrf2 }\end{array}$ & [107] \\
\hline & Local injection & $\begin{array}{c}5 \mu \mathrm{g} / \mathrm{mL}, 10 \mu \mathrm{g} / \mathrm{mL}, 20 \mu \mathrm{g} / \\
\mathrm{mL} / \text { week }\end{array}$ & 2 and 4 & $\begin{array}{l}\text { Decrease Pfirrmann MRI grade; HE: improve } \\
\text { the structure of the intervertebral disc in a dose- } \\
\text { dependent manner; immunohistochemistry: } \\
\text { increase the expression of collagen II in a dose- } \\
\text { dependent manner }\end{array}$ & [108] \\
\hline Wogonin & Local injection & $50 \mu \mathrm{M} /$ week & 4 and 8 & $\begin{array}{l}\text { Decrease Pfirrmann MRI grade; HE: IVD } \\
\text { morphology improvement }\end{array}$ & [111] \\
\hline Luteoloside & $\begin{array}{l}\text { Injected } \\
\text { intraperitoneally }\end{array}$ & $10 \mathrm{mg} / \mathrm{kg} / \mathrm{d}$ & 4 and 8 & $\begin{array}{c}\text { Decrease the Pfirrmann MRI grade; X-ray: } \\
\text { increased intervertebral space height; HE and } \\
\text { safranin-O fast green: IVD morphology } \\
\text { improvement }\end{array}$ & [114] \\
\hline Quercetin & $\begin{array}{l}\text { Injected } \\
\text { intraperitoneally }\end{array}$ & $100 \mathrm{mg} / \mathrm{kg} / \mathrm{d}$ & 8 & $\begin{array}{l}\text { X-ray: increased intervertebral space height; HE } \\
\text { and safranin-O fast green: IVD morphology } \\
\text { improvement; immunofluorescence: } \\
\text { downregulation of caspase-3 expression, } \\
\text { upregulation of SIRT1 expression }\end{array}$ & [117] \\
\hline \multirow{2}{*}{ Berberine } & $\begin{array}{l}\text { Injected } \\
\text { intraperitoneally }\end{array}$ & $150 \mathrm{mg} / \mathrm{kg} / \mathrm{d}$ & 8 & $\begin{array}{c}\text { Decrease Pfirrmann MRI grade; HE and } \\
\text { safranin-O fast green: IVD morphology } \\
\text { improvement; TUNEL: decreased rate of } \\
\text { positive cells }\end{array}$ & [128] \\
\hline & $\begin{array}{c}\text { Intragastric } \\
\text { administration }\end{array}$ & $150 \mathrm{mg} / \mathrm{kg} / \mathrm{d}$ & 4 & $\begin{array}{c}\text { Decrease Pfirrmann MRI grade; HE: IVD } \\
\text { morphology improvement; } \\
\text { immunofluorescence: downregulation of } \\
\text { caspase-3 expression }\end{array}$ & [129] \\
\hline Oxymatrine & Local injection & $\begin{array}{l}\text { Oxymatrine } 10 \mu \mathrm{M} \\
\text { Oxymatrine } \\
10 \mu \mathrm{M}+\mathrm{LIP} 100 \mu \mathrm{g} / \mu \mathrm{L}\end{array}$ & 4 & $\begin{array}{l}\text { X-ray radiology: oxymatrine-LIP can partially } \\
\text { restore the height of the IVD }\end{array}$ & [132] \\
\hline
\end{tabular}




\section{Conclusion and the Future}

Oxidative stress and inflammation accelerate IDD. The intervertebral disc accumulates ROS; NP cells secrete inflammatory cytokines that activate IDD signalling pathways, compromise NP cell function, and trigger disc dysfunction and structural changes. Increased apoptosis and ECM degradation are also involved. Inhibition of oxidative stress, inflammation, apoptosis, and ECM degradation may slow IDD progression. Natural products can prevent and treat human diseases at low cost, as recognised in Asia and elsewhere. Natural products reduce ROS, MDA, and $\mathrm{O}^{2-}$ production, lowering oxidative stress damage. Natural products inhibit the expression of the inflammatory cytokines IL- $1 \beta$, TNF- $\alpha$, COX-2, iNOS, PGE2, and IL-6, reducing injury to NP cells. Natural products inhibit apoptosis and regulate metabolism. Natural products have been shown (in preclinical studies) to slow IDD development. However, most studies regarding natural products are published in low-impact journals. The synergistic and multitargeting effects of natural products are not exhibited by synthetic drugs. A multitargeting multilevel approach may yield new IDD treatments; more work is needed. We hope that our review highlights the importance of natural products when seeking to treat and prevent IDD.

\section{Data Availability}

No data were used to support this study.

\section{Conflicts of Interest}

All authors declare no conflicts of interest.

\section{Authors' Contributions}

Hai-Wei Chen, Guang-Zhi Zhang, and Ming-Qiang Liu contributed equally to this work. Hai-Wei Chen, Guang-Zhi Zhang, Ming-Qiang Liu, and Xue-Wen Kang conceived and wrote the article. Ji-He Kang and Li-Juan Zhang contributed to making of figures. Hai-Wei Chen, Guang-Zhi Zhang, and Ming-Qiang Liu wrote and revised the manuscript. ZhaoHeng Wang, Ai-Xin Lin, and Wen-Zhao Liu contributed to proofreading of the article. All authors read and approved the final manuscript.

\section{Acknowledgments}

This work was supported by the Laboratory Animal Ethics Committee of the Second Hospital Medical of Lanzhou University (20JR10RA735), the Special Fund Project for Doctoral Training Programme of Lanzhou University Second Hospital (YJSBD-09), Lanzhou University Innovation and Entrepreneurship Cultivation Project (cxcy201906), and the Chinese Medicine Administration Research Project of Gansu Province (GZK-2019-46), and the Cuiying Technology Innovation Project of Lanzhou University Second Hospital (CY2019-MS10). The authors thank Textcheck (http://www.textcheck.com) for English language editing.

\section{References}

[1] G. E. Mosley, T. W. Evashwick-Rogler, A. Lai, and J. C. Iatridis, "Looking beyond the intervertebral disc: the need for behavioral assays in models of discogenic pain," Annals of the New York Academy of Sciences, vol. 1409, no. 1, pp. 51-66, 2017.

[2] J. L. Dieleman, J. Cao, A. Chapin et al., "US health care spending by payer and health condition, 1996-2016," JAMA, vol. 323, no. 9, pp. 863-884, 2020.

[3] F. Bach, S. A. de Vries, S. de Vries et al., “The species-specific regenerative effects of notochordal cell-conditioned medium on chondrocyte-like cells derived from degenerated human intervertebral discs," European Cells and Materials, vol. 30, pp. 132-147, 2015.

[4] S. M. Rider, S. Mizuno, and J. D. Kang, "Molecular mechanisms of intervertebral disc degeneration," Spine Surgery and Related Research, vol. 3, no. 1, pp. 1-11, 2015.

[5] C. Feng, H. Liu, M. Yang, Y. Zhang, B. Huang, and Y. Zhou, "Disc cell senescence in intervertebral disc degeneration: causes and molecular pathways," Cell Cycle, vol. 15, no. 13, pp. 1674-1684, 2016.

[6] C. Ruiz-Fernández, V. Francisco, J. Pino et al., "Molecular relationships among obesity, inflammation and intervertebral disc degeneration: are adipokines the common link?" International Journal of Molecular Sciences, vol. 208 pages, 2019.

[7] S. M. Richardson, G. Kalamegam, P. N. Pushparaj et al., "Mesenchymal stem cells in regenerative medicine: focus on articular cartilage and intervertebral disc regeneration," Methods, vol. 99, pp. 69-80, 2016.

[8] L. Du, Q. Yang, J. Zhang et al., "Engineering a biomimetic integrated scaffold for intervertebral disc replacement," Materials Science and Engineering: C, vol. 96, pp. 522-529, 2019.

[9] U. G. Longo, S. Petrillo, E. Franceschetti, N. Maffulli, and V. Denaro, "Growth factors and anticatabolic substances for prevention and management of intervertebral disc degeneration," Stem Cells International, vol. 2012, Article ID 897183, 9 pages, 2012.

[10] X. Cheng, G. Zhang, L. Zhang et al., "Mesenchymal stem cells deliver exogenous miR-21viaexosomes to inhibit nucleus pulposus cell apoptosis and reduce intervertebral disc degeneration," Journal of Cellular and Molecular Medicine, vol. 22, no. 1, pp. 261-276, 2018.

[11] R. D. Bowles and L. A. Setton, "Biomaterials for intervertebral disc regeneration and repair," Biomaterials, vol. 129, pp. 54-67, 2017.

[12] L. Shan, Z. Liu, L. Ci, C. Shuai, X. Lv, and J. Li, "Research progress on the anti-hepatic fibrosis action and mechanism of natural products," International Immunopharmacology, vol. 75, Article ID 105765, 2019.

[13] M. N. Uddin Chy, M. Adnan, M. R. Chowdhury et al., "Central and peripheral pain intervention by Ophiorrhiza rugosa leaves: potential underlying mechanisms and insight into the role of pain modulators," Journal of Ethnopharmacology, vol. 276, Article ID 114182, 2021.

[14] M. A. Freitas, A. Vasconcelos, E. C. D. Gonçalves et al., "Involvement of opioid system and TRPM8/TRPA1 channels in the antinociceptive effect of spirulina platensis," Biomolecules, vol. 11, no. 4, 2021.

[15] V. Hiebl, A. Ladurner, S. Latkolik, and V. M. Dirsch, "Natural products as modulators of the nuclear receptors and 
metabolic sensors LXR, FXR and RXR," Biotechnology Advances, vol. 36, no. 6, pp. 1657-1698, 2018.

[16] A. L. Harvey, R. Edrada-Ebel, and R. J. Quinn, "The reemergence of natural products for drug discovery in the genomics era," Nature Reviews Drug Discovery, vol. 14, no. 2, pp. 111-129, 2015.

[17] E. Küpeli Akkol, I. Tatlı Çankaya, G. Şeker Karatoprak, E. Carpar, E. Sobarzo-Sánchez, and R. Capasso, "Natural compounds as medical strategies in the prevention and treatment of psychiatric disorders seen in neurological diseases," Frontiers in Pharmacology, vol. 12, Article ID 669638, 2021.

[18] J. Wang, C. Huang, Z. Lin et al., "Polydatin suppresses nucleus pulposus cell senescence, promotes matrix homeostasis and attenuates intervertebral disc degeneration in rats," Journal of Cellular and Molecular Medicine, vol. 22, no. 11, pp. 5720-5731, 2018.

[19] X. Su, B. Liu, F. Gong et al., "Isofraxidin attenuates IL-1 $\beta$ induced inflammatory response in human nucleus pulposus cells," Journal of Cellular Biochemistry, vol. 120, no. 8, pp. 13302-13309, 2019.

[20] G. J. Kerr, M. A. Veras, M. K. M. Kim, and C. A. Séguin, "Decoding the intervertebral disc: unravelling the complexities of cell phenotypes and pathways associated with degeneration and mechanotransduction," Seminars in Cell \& Developmental Biology, vol. 62, pp. 94-103, 2017.

[21] J. W. Ashley, M. Enomoto-Iwamoto, L. J. Smith et al., "Intervertebral disc development and disease-related genetic polymorphisms," Genes \& Diseases, vol. 3, no. 3, pp. 171-177, 2016.

[22] P. Sampara, R. R. Banala, S. K. Vemuri, G. R. Av, and S. Gpv, "Understanding the molecular biology of intervertebral disc degeneration and potential gene therapy strategies for regeneration: a review," Gene Therapy, vol. 25, no. 2, pp. 67-82, 2018.

[23] Z. Johnson, Z. R. Schoepflin, Z. Schoepflin, H. Choi, I. Shapiro, and M. Risbud, "Disc in flames: roles of TNF- $\alpha$ and IL-1 $\beta$ in intervertebral disc degeneration," European Cells and Materials, vol. 30, pp. 104-117, 2015.

[24] J. Daniels, A. A. L. Binch, and C. L. Le Maitre, "Inhibiting IL1 signaling pathways to inhibit catabolic processes in disc degeneration," Journal of Orthopaedic Research, vol. 35, no. 1, pp. 74-85, 2017.

[25] N. V. Vo, R. A. Hartman, P. R. Patil et al., "Molecular mechanisms of biological aging in intervertebral discs," Journal of Orthopaedic Research, vol. 34, no. 8, pp. 12891306, 2016.

[26] F. Zhang, X. Zhao, H. Shen, and C. Zhang, "Molecular mechanisms of cell death in intervertebral disc degeneration (review)," International Journal of Molecular Medicine, vol. 37, no. 6, pp. 1439-1448, 2016.

[27] S. Yang, F. Zhang, J. Ma, and W. Ding, "Intervertebral disc ageing and degeneration: the antiapoptotic effect of oestrogen," Ageing Research Reviews, vol. 57, Article ID 100978, 2020.

[28] Z. Ling, L. Li, Y. Chen et al., "Changes of the end plate cartilage are associated with intervertebral disc degeneration: a quantitative magnetic resonance imaging study in rhesus monkeys and humans," Journal of Orthopaedic Translation, vol. 24, pp. 23-31, 2020.

[29] W. Yang, X.-H. Yu, C. Wang et al., "Interleukin- $1 \beta$ in intervertebral disk degeneration," Clinica Chimica Acta, vol. 450, pp. 262-272, 2015.
[30] L. A. Nasto, A. R. Robinson, K. Ngo et al., "Mitochondrialderived reactive oxygen species (ROS) play a causal role in aging-related intervertebral disc degeneration," Journal of Orthopaedic Research, vol. 31, no. 7, pp. 1150-1157, 2013.

[31] C. Feng, M. Yang, M. Lan et al., "ROS: crucial intermediators in the pathogenesis of intervertebral disc degeneration," Oxidative Medicine and Cellular Longevity, vol. 2017, Article ID 5601593, 12 pages, 2017.

[32] P. Davalli, T. Mitic, A. Caporali, A. Lauriola, and D. D'Arca, "ROS, cell senescence, and novel molecular mechanisms in aging and age-related diseases," Oxidative Medicine and Cellular Longevity, vol. 2016, Article ID 3565127, 18 pages, 2016.

[33] Z. Zhang, T. Xu, J. Chen et al., "Parkin-mediated mitophagy as a potential therapeutic target for intervertebral disc degeneration," Cell Death \& Disease, vol. 9, no. 10, 980 pages, 2018.

[34] G.-Z. Zhang, Y.-J. Deng, Q.-Q. Xie et al., "Sirtuins and intervertebral disc degeneration: roles in inflammation, oxidative stress, and mitochondrial function," Clinica Chimica Acta, vol. 508, pp. 33-42, 2020.

[35] K. Sun, X. Jing, J. Guo, X. Yao, and F. Guo, "Mitophagy in degenerative joint diseases," Autophagy, vol. 24, no. 9, pp. 1-11, 2020.

[36] G. T. Desmoulin, V. Pradhan, and T. E. Milner, "Mechanical aspects of intervertebral disc injury and implications on biomechanics," Spine, vol. 45, no. 8, pp. E457-E464, 2020.

[37] P.-P. A. Vergroesen, I. Kingma, K. S. Emanuel et al., "Mechanics and biology in intervertebral disc degeneration: a vicious circle," Osteoarthritis and Cartilage, vol. 23, no. 7, pp. 1057-1070, 2015.

[38] N. Kos, L. Gradisnik, and T. Velnar, "A brief review of the degenerative intervertebral disc disease," Medical Archives, vol. 73, no. 6, pp. 421-424, 2019.

[39] S. E. Navone, G. Marfia, A. Giannoni et al., "Inflammatory mediators and signalling pathways controlling intervertebral disc degeneration," Histology and Histopathology, vol. 32, no. 6, pp. 523-542, 2017.

[40] P. Cazzanelli and K. Wuertz-Kozak, "MicroRNAs in intervertebral disc degeneration, apoptosis, inflammation, and mechanobiology," International Journal of Molecular Sciences, vol. 2110 pages, 2020.

[41] W. J. Wang, X. H. Yu, C. Wang et al., "MMPs and ADAMTSs in intervertebral disc degeneration," Clinica Chimica Acta, vol. 448, pp. 238-246, 2013.

[42] A. Rauf, M. Imran, H. A. R. Suleria, B. Ahmad, D. G. Peters, and M. S. Mubarak, "A comprehensive review of the health perspectives of resveratrol," Food \& Function, vol. 8, no. 12, pp. 4284-4305, 2017.

[43] X. Kou and N. Chen, "Resveratrol as a natural autophagy regulator for prevention and treatment of Alzheimer's disease," Nutrients, vol. 9, no. 9, 927 pages, 2017.

[44] Y. Jiang, Z. Xie, J. Yu, and L. Fu, "Resveratrol inhibits IL- $1 \beta$ mediated nucleus pulposus cell apoptosis through regulating the PI3K/Akt pathway," Bioscience Reports, vol. 39, no. 3, 2017.

[45] S.-D. Yang, L. Ma, D.-L. Yang, and W.-Y. Ding, "Combined effect of $17 \beta$-estradiol and resveratrol against apoptosis induced by interleukin-1 $\beta$ in rat nucleus pulposus cells via PI3K/Akt/caspase-3 pathway," PeerJ, vol. 4, Article ID e1640, 2016.

[46] Z. Zhang, F. Wen, C. He, and J. Yu, "Resveratrol attenuates mechanical compression-induced nucleus pulposus cell apoptosis through regulating the ERK1/2 signaling pathway 
in a disc organ culture," Bioscience Reports, vol. 38, no. 2, 2018.

[47] Y. Jiang, G. Dong, and Y. Song, "Nucleus pulposus cell senescence is alleviated by resveratrol through regulating the ROS/NF- $\kappa$ B pathway under high-magnitude compression," Bioscience Reports, vol. 38, no. 4, 2018.

[48] J. Guo, M. Shao, F. Lu, J. Jiang, and X. Xia, "Role of Sirt1 plays in nucleus pulposus cells and intervertebral disc degeneration," Spine, vol. 42, no. 13, pp. E757-E766, 2017.

[49] X.-H. Wang, L. Zhu, X. Hong et al., "Resveratrol attenuated TNF- $\alpha$-induced MMP-3 expression in human nucleus pulposus cells by activating autophagy via AMPK/SIRT1 signaling pathway," Experimental Biology and Medicine, vol. 241, no. 8, pp. 848-853, 2016.

[50] J. W. Wu, J. J. Wang, J. B. Chen et al., "Resveratrol could reverse the expression of SIRT1 and MMP-1 in vitro," Genetics and Molecular Research, vol. 14, no. 4, pp. 1238612393, 2015.

[51] J. L. Shen, Z. M. Hu, X. M. Zhong, X. J. Zhang, and W. Jiang, "Resveratrol stimulates extracellular matrix synthesis in degenerative nucleus pulposus cells via upregulation of SIRT1," Xi Bao Yu Fen Zi Mian Yi Xue Za Zhi, vol. 28, no. 11, pp. 1146-1150, 2012.

[52] X. Guo, X. Bai, F. Zhang, L. Zheng, W. Ding, and S. Yang, "Resveratrol protects against apoptosis induced by interleukin- $1 \beta$ in nucleus pulposus cells via activating mTOR/ caspase-3 and GSK-3 $\beta /$ caspase-3 pathways," Bioscience Reports, vol. 40, no. 7, 2020.

[53] J. He, A. Zhang, Z. Song et al., "The resistant effect of SIRT1 in oxidative stress-induced senescence of rat nucleus pulposus cell is regulated by Akt-FoxO1 pathway," Bioscience Reports, vol. 39, no. 5, 2019.

[54] C. Jia, J. Zhang, L. Yu et al., "Antifungal activity of coumarin against Candida albicans is related to apoptosis," Frontiers in Cellular and Infection Microbiology, vol. 8445 pages, 2018.

[55] J. H. C. e. Silva, R. S. Ferreira, E. P. Pereira et al., "Amburana cearensis: pharmacological and neuroprotective effects of its compounds," Molecules, vol. 25, no. 15, 3394 pages, 2020.

[56] R. Li, C. Zhao, M. Yao, Y. Song, Y. Wu, and A. Wen, "Analgesic effect of coumarins from Radix angelicae pubescentis is mediated by inflammatory factors and TRPV1 in a spared nerve injury model of neuropathic pain," Journal of Ethnopharmacology, vol. 195, pp. 81-88, 2017.

[57] F. G. Medina, J. G. Marrero, M. Macías-Alonso et al., "Coumarin heterocyclic derivatives: chemical synthesis and biological activity," Natural Product Reports, vol. 32, no. 10, pp. 1472-1507, 2015.

[58] E. Küpeli Akkol, Y. Genç, B. Karpuz, E. Sobarzo-Sánchez, and R. Capasso, "Coumarins and coumarin-related compounds in pharmacotherapy of cancer," Cancers, vol. 12, no. 7, 1959 pages, 2020.

[59] S. Ahmed, H. Khan, M. Aschner, H. Mirzae, E. Küpeli Akkol, and R. Capasso, "Anticancer potential of furanocoumarins: mechanistic and therapeutic aspects," International Journal of Molecular Sciences, vol. 21, no. 16, 5622 pages, 2020.

[60] W.-L. Wu, C.-F. Cheng, W.-H. Sun, C.-W. Wong, and C.-C. Chen, "Targeting ASIC3 for pain, anxiety, and insulin resistance," Pharmacology \& Therapeutics, vol. 134, no. 2, pp. 127-138, 2012.

[61] Q. L. He, Y. Chen, J. Qin et al., "Osthole, a herbal compound, alleviates nucleus pulposus-evoked nociceptive responses through the suppression of overexpression of acid-sensing ion channel 3 (ASIC3) in rat dorsal root ganglion," Medical Science Monitor: International Medical Journal of
Experimental and Clinical Research, vol. 18, no. 6, pp. BR229-BR236, 2012.

[62] J. Ge, L. Chen, Y. Yang, X. Lu, and Z. Xiang, "Sparstolonin B prevents lumbar intervertebral disc degeneration through toll like receptor 4, NADPH oxidase activation and the protein kinase B signaling pathway," Molecular Medicine Reports, vol. 17, no. 1, pp. 1347-1353, 2018.

[63] B. Kocaadam and N. Şanlier, "Curcumin, an active component of turmeric (Curcuma longa), and its effects on health," Critical Reviews in Food Science and Nutrition, vol. 57, no. 13, pp. 2889-2895, 2017.

[64] H. Li, A. Sureda, H. P. Devkota et al., "Curcumin, the golden spice in treating cardiovascular diseases," Biotechnology Advances, vol. 38, Article ID 107343, 2020.

[65] A. Bielak-Zmijewska, W. Grabowska, A. Ciolko et al., "The role of curcumin in the modulation of ageing," International Journal of Molecular Sciences, vol. 20, no. 5, 1239 pages, 2019.

[66] A. L. Lopresti, "The problem of curcumin and its bioavailability: could its gastrointestinal influence contribute to its overall health-enhancing effects?" Advances in Nutrition, vol. 9, no. 1, pp. 41-50, 2018.

[67] S. Sundar Dhilip Kumar, N. N. Houreld, and H. Abrahamse, "Therapeutic potential and recent advances of curcumin in the treatment of aging-associated diseases," Molecules, vol. 23, no. 4, 2018.

[68] L. Kang, Q. Xiang, S. Zhan et al., "Restoration of autophagic flux rescues oxidative damage and mitochondrial dysfunction to protect against intervertebral disc degeneration," Oxidative Medicine and Cellular Longevity, vol. 2019, Article ID 7810320, 27 pages, 2019.

[69] H. Cherif, D. Bisson, P. Jarzem, M. Weber, J. Ouellet, and L. Haglund, "Curcumin and o-vanillin exhibit evidence of senolytic activity in human IVD cells in vitro," Journal of Clinical Medicine, vol. 8, no. 4, 433 pages, 2019.

[70] H. Cherif, D. G. Bisson, M. Mannarino, O. Rabau, J. A. Ouellet, and L. Haglund, "Senotherapeutic drugs for human intervertebral disc degeneration and low back pain," Elife, vol. 9, Article ID e54693, 2020.

[71] C. P. Ong, W. L. Lee, Y. Q. Tang, and W. H. Yap, "Honokiol: a review of its anticancer potential and mechanisms," Cancers (Basel), vol. 12, no. 1, 48 pages, 2020.

[72] K. Banik, A. M. Ranaware, V. Deshpande et al., "Honokiol for cancer therapeutics: a traditional medicine that can modulate multiple oncogenic targets," Pharmacological Research, vol. 144, pp. 192-209, 2019.

[73] J. Pan, Y. Lee, Y. Wang, and M. You, "Honokiol targets mitochondria to halt cancer progression and metastasis," Molecular Nutrition \& Food Research, vol. 60, no. 6, pp. 1383-1395, 2019.

[74] P. Tang, J.-M. Gu, Z.-A. Xie et al., "Honokiol alleviates the degeneration of intervertebral disc via suppressing the activation of TXNIP-NLRP3 inflammasome signal pathway," Free Radical Biology and Medicine, vol. 120, pp. 368-379, 2018.

[75] W. Sun, C. Liu, Q. Chen, N. Liu, Y. Yan, and B. Liu, "SIRT3: a new regulator of cardiovascular diseases," Oxidative Medicine and Cellular Longevity, vol. 2018, Article ID 7293861, 11 pages, 2018

[76] J. Wang, M. Nisar, C. Huang et al., "Small molecule natural compound agonist of SIRT3 as a therapeutic target for the treatment of intervertebral disc degeneration," Experimental \& Molecular Medicine, vol. 50, no. 11, pp. 1-14, 2018.

[77] C.-H. Chen, C.-J. Chiang, L.-C. Wu, C.-H. Yang, Y.-J. Kuo, and T.-H. Tsai, "In vitro penetration and in vivo distribution 
of Honokiol into the intervertebral disc in rat," Analytical Sciences, vol. 31, no. 12, pp. 1297-1302, 2015.

[78] T. Qin, A. Rasul, A. Sarfraz et al., "Salvianolic acid A \& B: potential cytotoxic polyphenols in battle against cancer via targeting multiple signaling pathways," International Journal of Biological Sciences, vol. 15, no. 10, pp. 2256-2264, 2019.

[79] S. Dai, T. Liang, X. Shi, Z. Luo, and H. Yang, "Salvianolic acid $B$ protects intervertebral discs from oxidative stress-induced degeneration via activation of the JAK2/STAT3 signaling pathway," Oxidative Medicine and Cellular Longevity, vol. 2021, Article ID 6672978, 13 pages, 2021.

[80] H.-S. Yan, C. Hang, S.-W. Chen, K.-K. Wang, and P. Bo, "Salvianolic acid B combined with mesenchymal stem cells contributes to nucleus pulposus regeneration," Connective Tissue Research, vol. 61, no. 5, pp. 435-444, 2020.

[81] M. Prasanth, B. Sivamaruthi, C. Chaiyasut, and T. Tencomnao, "A review of the role of green tea (camellia sinensis) in antiphotoaging, stress resistance, neuroprotection, and autophagy," Nutrients, vol. 11, no. 2, pp. 474-2, 2019.

[82] D. Song, J. Ge, Y. Wang et al., “Tea polyphenol attenuates oxidative stress-induced degeneration of intervertebral discs by regulating the keap1/nrf2/ARE pathway," Oxidative Medicine and Cellular Longevity, vol. 2021, Article ID 6684147, 13 pages, 2021.

[83] A. R. Khalatbary and E. Khademi, "The green tea polyphenolic catechin epigallocatechin gallate and neuroprotection," Nutritional Neuroscience, vol. 23, no. 4, pp. 281-294, 2020.

[84] Y. Tian, Z. Bao, Y. Ji, X. Mei, and H. Yang, "Epigallocatechin3-Gallate protects $\mathrm{H}_{2} \mathrm{O}_{2}$-induced nucleus pulposus cell apoptosis and inflammation by inhibiting cGAS/sting/NLRP3 activation," Drug Design, Development and Therapy, vol. 14, pp. 2113-2122, 2020.

[85] J. N. R. Moni, M. Adnan, A. M. Tareq et al., “Therapeutic potentials of syzygium fruticosum fruit (seed) reflected into an array of pharmacological assays and prospective receptors-mediated pathways," Life (Basel), vol. 11, no. 2, 2021.

[86] B. A. Khan, T. Mahmood, F. Menaa et al., "New perspectives on the efficacy of gallic acid in cosmetics \& nanocosmeceuticals," Current Pharmaceutical Design, vol. 24, no. 43, pp. 5181-5187, 2018.

[87] Y. Huang, J. Chen, T. Jiang et al., "Gallic acid inhibits the release of ADAMTS4 in nucleus pulposus cells by inhibiting p65 phosphorylation and acetylation of the NF- $\kappa$ B signaling pathway," Oncotarget, vol. 8, no. 29, pp. 47665-47674, 2018.

[88] A. F. Majdalawieh, M. Massri, and G. K. Nasrallah, "A comprehensive review on the anti-cancer properties and mechanisms of action of sesamin, a lignan in sesame seeds (Sesamum indicum)," European Journal of Pharmacology, vol. 815, pp. 512-521, 2017.

[89] K. Li, Y. Li, B. Xu, L. Mao, and J. Zhao, "Sesamin inhibits lipopolysaccharide-induced inflammation and extracellular matrix catabolism in rat intervertebral disc," Connective Tissue Research, vol. 57, no. 5, pp. 347-359, 2016.

[90] C. Angeloni, M. C. Barbalace, and S. Hrelia, "Icariin and its metabolites as potential protective phytochemicals against Alzheimer's disease," Frontiers in Pharmacology, vol. 10271 pages, 2019.

[91] J. Fang and Y. Zhang, "Icariin, an anti-atherosclerotic drug from Chinese medicinal herb horny goat weed," Frontiers in Pharmacology, vol. 8734 pages, 2017.

[92] C.-Y. Shen, J.-G. Jiang, L. Yang, D.-W. Wang, and W. Zhu, "Anti-ageing active ingredients from herbs and nutraceuticals used in traditional Chinese medicine: pharmacological mechanisms and implications for drug discovery," British Journal of Pharmacology, vol. 174, no. 11, pp. 1395-1425, 2017.

[93] W. Hua, S. Li, R. Luo et al., "Icariin protects human nucleus pulposus cells from hydrogen peroxide-induced mitochondria-mediated apoptosis by activating nuclear factor erythroid 2-related factor 2," Biochimica et Biophysica Acta. Molecular Basis of Disease, vol. 1866, no. 1, Article ID 165575, 2020.

[94] W. Hua, Y. Zhang, X. Wu et al., "Icariin attenuates interleukin-1 $\beta$-induced inflammatory response in human nucleus pulposus cells," Current Pharmaceutical Design, vol. 23, no. 39, pp. 6071-6078, 2017.

[95] X. Deng, S. Chen, D. Zheng, Z. Shao, H. Liang, and H. Hu, "Icariin prevents $\mathrm{H}_{2} \mathrm{O}_{2}$-induced apoptosis via the PI3K/Akt pathway in rat nucleus pulposus intervertebral disc cells," Evidence-Based Complementary and Alternative Medicine, vol. 2017, Article ID 2694261, 10 pages, 2017.

[96] M. A. Alam, N. Subhan, M. M. Rahman, S. J. Uddin, H. M. Reza, and S. D. Sarker, "Effect of citrus flavonoids, naringin and naringenin, on metabolic syndrome and their mechanisms of action," Advances in Nutrition, vol. 5, no. 4, pp. 404-417, 2014.

[97] S. Ahmed, H. Khan, M. Aschner, M. M. Hasan, and S. T. S. Hassan, "Therapeutic potential of naringin in neurological disorders," Food and Chemical Toxicology: An International Journal Published for the British Industrial Biological Research Association, vol. 132, Article ID 110646, 2014.

[98] R. Heidary Moghaddam, Z. Samimi, S. Z. Moradi, P. J. Little, S. Xu, and M. H. Farzaei, "Naringenin and naringin in cardiovascular disease prevention: a preclinical review," European Journal of Pharmacology, vol. 887, Article ID 173535, 2020.

[99] P. Lavrador, V. M. Gaspar, and J. F. Mano, "Bioinspired bone therapies using naringin: applications and advances," Drug Discovery Today, vol. 23, no. 6, pp. 1293-1304, 2018.

[100] N. Li, C. Whitaker, Z. Xu, M. Heggeness, and S.-Y. Yang, "Therapeutic effects of naringin on degenerative human nucleus pulposus cells for discogenic low back pain," The Spine Journal, vol. 16, no. 10, pp. 1231-1237, 2016.

[101] Z. Zhang, C. Wang, J. Lin et al., "Therapeutic potential of naringin for intervertebral disc degeneration: involvement of autophagy against oxidative stress-induced apoptosis in nucleus pulposus cells," The American Journal of Chinese Medicine, vol. 46, no. 7, pp. 1-20, 2018.

[102] G. Gao, F. Chang, T. Zhang et al., "Naringin protects against interleukin $1 \beta$ (IL-1 $\beta$ )-Induced human nucleus pulposus cells degeneration via downregulation nuclear factor kappa $\mathrm{B}$ $(\mathrm{NF}-\kappa \mathrm{B})$ pathway and p53 expression," Medical Science Monitor, vol. 25, pp. 9963-9972, 2019.

[103] L.-P. Nan, F. Wang, D. Ran et al., "Naringin alleviates $\mathrm{H}_{2} \mathrm{O}_{2}$ induced apoptosis via the PI3K/Akt pathway in rat nucleus pulposus-derived mesenchymal stem cells," Connective Tissue Research, vol. 61, no. 6, pp. 554-567, 2020.

[104] X. Xin, C. Chen, Y. Y. Hu, and Q. Feng, "Protective effect of genistein on nonalcoholic fatty liver disease (NAFLD)," Biomedicine \& Pharmacotherapy = Biomedecine \& Pharmacotherapie, vol. 117, Article ID 109047, 2019.

[105] G. Bhattarai, S. B. Poudel, S.-H. Kook, and J.-C. Lee, "Antiinflammatory, anti-osteoclastic, and antioxidant activities of genistein protect against alveolar bone loss and periodontal tissue degradation in a mouse model of periodontitis," 
Journal of Biomedical Materials Research Part A, vol. 105, no. 9, pp. 2510-2521, 2017.

[106] C. Shen, W. Cheng, P. Yu et al., "Resveratrol pretreatment attenuates injury and promotes proliferation of neural stem cells following oxygen-glucose deprivation/reoxygenation by upregulating the expression of Nrf2, HO-1 and NQO1 in vitro," Molecular Medicine Reports, vol. 14, no. 4, pp. 3646-3654, 2016.

[107] K. Wang, S. Hu, B. Wang, J. Wang, X. Wang, and C. Xu, "Genistein protects intervertebral discs from degeneration via Nrf2-mediated antioxidant defense system: an in vitro and in vivo study," Journal of Cellular Physiology, vol. 234, no. 9, 2019.

[108] J. Ge, Q. Zhou, X. Cheng et al., "The protein tyrosine kinase inhibitor, Genistein, delays intervertebral disc degeneration in rats by inhibiting the p38 pathway-mediated inflammatory response," Aging, vol. 12, no. 3, pp. 2246-2260, 2020.

[109] X. Wu, H. Zhang, J. M. Salmani, R. Fu, and B. Chen, "Advances of wogonin, an extract from Scutellaria baicalensis, for the treatment of multiple tumors," OncoTargets and Therapy, vol. 9, pp. 2935-2943, 2016.

[110] S. Khan and M. A. Kamal, "Can wogonin be used in controlling diabetic cardiomyopathy?" Current Pharmaceutical Design, vol. 25, no. 19, pp. 2171-2177, 2019.

[111] W. Fang, X. Zhou, J. Wang et al., "Wogonin mitigates intervertebral disc degeneration through the Nrf2/ARE and MAPK signaling pathways," International Immunopharmacology, vol. 65, pp. 539-549, 2018.

[112] C.-Y. Shi, X.-B. He, C. Zhao, and H.-J. Wang, "Luteoloside exerts analgesic effect in a complete freund's adjuvant-induced inflammatory model via inhibiting interleukin- $1 \beta$ expression and macrophage/microglia activation," Frontiers in Pharmacology, vol. 111158 pages, 2020.

[113] Q. Li, Z. Tian, M. Wang et al., "Luteoloside attenuates neuroinflammation in focal cerebral ischemia in rats via regulation of the PPAR $\gamma / \mathrm{Nrf} 2 / \mathrm{NF}-\kappa \mathrm{B}$ signaling pathway," International Immunopharmacology, vol. 66, pp. 309-316, 2019.

[114] J. Lin, J. Chen, Z. Zhang et al., "Luteoloside inhibits IL-1 $\beta$ induced apoptosis and catabolism in nucleus pulposus cells and ameliorates intervertebral disk degeneration," Frontiers in Pharmacology, vol. 10868 pages, 2019.

[115] R. V. Patel, B. M. Mistry, S. K. Shinde, R. Syed, V. Singh, and H.-S. Shin, "Therapeutic potential of quercetin as a cardiovascular agent," European Journal of Medicinal Chemistry, vol. 155, pp. 889-904, 2018.

[116] M. S. Bari, L. Khandokar, E. Haque et al., "Ethnomedicinal uses, phytochemistry, and biological activities of plants of the genus Gynura," Journal of Ethnopharmacology, vol. 271, Article ID 113834, 2021.

[117] D. Wang, X. He, D. Wang et al., "Quercetin suppresses apoptosis and attenuates intervertebral disc degeneration via the SIRT1-autophagy pathway," Frontiers in Cell and Developmental Biology, vol. 8, Article ID 613006, 2020.

[118] Z. Shao, B. Wang, Y. Shi et al., "Senolytic agent Quercetin ameliorates intervertebral disc degeneration via the Nrf2/ NF- $\kappa \mathrm{B}$ axis," Osteoarthritis and Cartilage, vol. 29, no. 3, pp. 413-422, 2021.

[119] H. S. Tuli, V. Aggarwal, J. Kaur et al., "Baicalein: a metabolite with promising antineoplastic activity," Life Sciences, vol. 259, Article ID 118183, 2020.

[120] H. Jin, Q. Wang, J. Wu et al., "Baicalein inhibits the IL- $1 \beta$ induced inflammatory response in nucleus pulposus cells and attenuates disc degeneration in vivo," Inflammation, vol. 42, no. 3, pp. 1032-1044, 2019.

[121] B. Salehi, A. Venditti, M. Sharifi-Rad et al., "The therapeutic potential of apigenin," International Journal of Molecular Sciences, vol. 20, no. 6, 2019.

[122] F. Ding and X. Li, "Apigenin mitigates intervertebral disc degeneration through the amelioration of tumor necrosis factor $\alpha$ (TNF- $\alpha)$ signaling pathway," Medical Science Monitor: International Medical Journal of Experimental and Clinical Research, vol. 26, Article ID e924587, 2020.

[123] S. K. Wong, K.-Y. Chin, and S. Ima-Nirwana, “The osteoprotective effects of kaempferol: the evidence from in vivo and in vitro studies," Drug Design, Development and Therapy, vol. 13, pp. 3497-3514, 2019.

[124] J. Zhu, H. Tang, Z. Zhang et al., "Kaempferol slows intervertebral disc degeneration by modifying LPS-induced osteogenesis/adipogenesis imbalance and inflammation response in BMSCs," International Immunopharmacology, vol. 43, pp. 236-242, 2017.

[125] X. Feng, A. Sureda, S. Jafari et al., "Berberine in cardiovascular and metabolic diseases: from mechanisms to therapeutics," Theranostics, vol. 9, no. 7, pp. 1923-1951, 2019.

[126] Y. Jin, D. B. Khadka, and W.-J. Cho, "Pharmacological effects of berberine and its derivatives: a patent update," Expert Opinion on Therapeutic Patents, vol. 26, no. 2, pp. 229-243, 2016.

[127] L. Lu, J. Hu, Q. Wu et al., “Berberine prevents human nucleus pulposus cells from IL- $1 \beta$-induced extracellular matrix degradation and apoptosis by inhibiting the NF- $\kappa$ B pathway," International Journal of Molecular Medicine, vol. 43, no. 4, pp. 1679-1686, 2019.

[128] R. Luo, Z. Liao, Y. Song et al., "Berberine ameliorates oxidative stress-induced apoptosis by modulating ER stress and autophagy in human nucleus pulposus cells," Life Sciences, vol. 228, pp. 85-97, 2019.

[129] Y. Chen, Z. Zheng, J. Wang et al., "Berberine suppresses apoptosis and extracellular matrix (ECM) degradation in nucleus pulposus cells and ameliorates disc degeneration in a rodent model," International Journal of Biological Sciences, vol. 14, no. 6, pp. 682-692, 2018.

[130] X. Lan, J. Zhao, Y. Zhang, Y. Chen, Y. Liu, and F. Xu, "Oxymatrine exerts organ- and tissue-protective effects by regulating inflammation, oxidative stress, apoptosis, and fibrosis: from bench to bedside," Pharmacological Research, vol. 151, Article ID 104541, 2020.

[131] K. Wei, J. Dai, Z. Wang et al., "Oxymatrine suppresses IL-1 $\beta$ induced degradation of the nucleus pulposus cell and extracellular matrix through the TLR4/NF- $\kappa \mathrm{B}$ signaling pathway," Experimental Biology and Medicine, vol. 245, no. 6, pp. 532-541, 2020.

[132] H. Wang, Y. Ding, W. Zhang et al., "Oxymatrine liposomes for intervertebral disc treatment: formulation, in vitro and vivo assessments," Drug Design, Development and Therapy, vol. 14, pp. 921-931, 2020.

[133] S. Mahmud, G. K. Paul, M. Afroze et al., "Efficacy of phytochemicals derived from Avicennia officinalis for the management of COVID-19: a combined in silico and biochemical study," Molecules, vol. 26, no. 8, 2210 pages, 2021.

[134] I. U. Haq, M. Imran, M. Nadeem, T. Tufail, T. A. Gondal, and M. S. Mubarak, "Piperine: a review of its biological effects," Phytotherapy Research, vol. 35, no. 2, pp. 680-700, 2020.

[135] Y. Li, K. Li, Y. Hu, B. Xu, and J. Zhao, "Piperine mediates LPS induced inflammatory and catabolic effects in rat 
intervertebral disc," International Journal of Clinical and Experimental Pathology, vol. 8, no. 6, pp. 6203-6213, 2015.

[136] S. Hossain, Z. Urbi, H. Karuniawati et al., "Andrographis paniculata (burm. F.) wall. Ex nees: an updated review of phytochemistry, antimicrobial pharmacology, and clinical safety and efficacy," Life, vol. 11, no. 4, 348 pages, 2021.

[137] E. Mussard, A. Cesaro, E. Lespessailles, B. Legrain, S. Berteina-Raboin, and H. Toumi, "Andrographolide, a natural antioxidant: an update," Antioxidants, vol. 8, no. 12, 571 pages, 2019.

[138] J. Liu, T. Jiang, M. He et al., “Andrographolide prevents human nucleus pulposus cells against degeneration by inhibiting the NF- $\kappa$ B pathway," Journal of Cellular Physiology, vol. 234, no. 6, pp. 9631-9639, 2019.

[139] L. Zhang, Q. Chen, H. Wang, J. Yang, and S. Sheng, "Andrographolide mitigates IL- $1 \beta$-induced human nucleus pulposus cells degeneration through the TLR4/MyD88/NF$\kappa \mathrm{B}$ signaling pathway," Molecular Medicine Reports, vol. 18, no. 6, pp. 5427-5436, 2018.

[140] Z.-G. Sun, T.-T. Zhao, N. Lu, Y.-A. Yang, and H.-L. Zhu, "Research progress of glycyrrhizic acid on antiviral activity," Mini-Reviews in Medicinal Chemistry, vol. 19, no. 10, pp. 826-832, 2019.

[141] X. Liu, J. Zhuang, D. Wang et al., "Glycyrrhizin suppresses inflammation and cell apoptosis by inhibition of HMGB1 via p38/p-JUK signaling pathway in attenuating intervertebral disc degeneration," American Journal of Translational Research, vol. 11, no. 8, pp. 5105-5113, 2019.

[142] C.-X. Zhang, T. Wang, J.-F. Ma, Y. Liu, Z.-G. Zhou, and D.-C. Wang, "Protective effect of CDDO-ethyl amide against high-glucose-induced oxidative injury via the $\mathrm{Nrf} 2 / \mathrm{HO}-1$ pathway," The Spine Journal, vol. 17, no. 7, pp. 1017-1025, 2017.

[143] V. Martínez, A. Iriondo De-Hond, F. Borrelli, R. Capasso, M. D. Del Castillo, and R. Abalo, "Cannabidiol and other non-psychoactive cannabinoids for prevention and treatment of gastrointestinal disorders: useful nutraceuticals?" International Journal of Molecular Sciences, vol. 21, no. 9, 3067 pages, 2020.

[144] G. Vieira, J. Cavalli, E. C. D. Gonçalves et al., “Antidepressant-like effect of terpineol in an inflammatory model of depression: involvement of the cannabinoid system and D2 dopamine receptor," Biomolecules, vol. 10, no. 5, pp. 792-5, 2020.

[145] J. W. Silveira, A. C. Issy, V. A. Castania et al., "Protective effects of cannabidiol on lesion-induced intervertebral disc degeneration," PLoS One, vol. 9, no. 12, Article ID e113161, 2014.

[146] Y. J. Kim, D. Zhang, and D. C. Yang, "Biosynthesis and biotechnological production of ginsenosides," Biotechnology Advances, vol. 33, no. 6, pp. 717-735, 2015.

[147] M. Zheng, Y. Xin, Y. Li et al., "Ginsenosides: a potential neuroprotective agent," BioMed Research International, vol. 2018, Article ID 8174345, 11 pages, 2018.

[148] L. Yu, Y. Hao, C. Peng et al., "Effect of Ginsenoside Rg1 on the intervertebral disc degeneration rats and the degenerative pulposus cells and its mechanism," Biomedicine \& Pharmacotherapy, vol. 123109738 pages, 2020.

[149] J. Chen, G.-Z. Liu, Q. Sun et al., "Protective effects of ginsenoside $\operatorname{Rg} 3$ on TNF- $\alpha$-induced human nucleus pulposus cells through inhibiting NF- $\kappa \mathrm{B}$ signaling pathway," Life Sciences, vol. 216, pp. 1-9, 2019.

[150] T. Li, M. Lv, X. Chen, Y. Yu, G. Zang, and Z. Tang, "Plumbagin inhibits proliferation and induces apoptosis of hepatocellular carcinoma by downregulating the expression of SIVA," Drug Design, Development and Therapy, vol. 13, pp. 1289-1300, 2019.

[151] H. Chu, H. Yu, D. Ren, K. Zhu, and H. Huang, "Plumbagin exerts protective effects in nucleus pulposus cells by attenuating hydrogen peroxide-induced oxidative stress, inflammation and apoptosis through NF- $\kappa \mathrm{B}$ and Nrf-2," International Journal of Molecular Medicine, vol. 37, no. 6, pp. 1669-1676, 2016.

[152] M. F. Khan, F. B. Kader, M. Arman et al., "Pharmacological insights and prediction of lead bioactive isolates of Dita bark through experimental and computer-aided mechanism," Biomedicine \& Pharmacotherapy, vol. 131, Article ID 110774, 2020.

[153] F. I. Fahad, N. Barua, M. S. Islam et al., "Investigation of the pharmacological properties of lepidagathis hyalina nees through experimental approaches," Life, vol. 11, no. 3, 180 pages, 2021.

[154] G. Bjørklund, N. A. Meguid, M. A. El-Bana et al., "Oxidative stress in autism spectrum disorder," Molecular Neurobiology, vol. 57, no. 5, pp. 2314-2332, 2020.

[155] L. Kang, Y. Tian, X. Guo, X. Chu, and Y. Xue, "Long noncoding RNA ANPODRT overexpression protects nucleus pulposus cells from oxidative stress and apoptosis by activating keap1-nrf2 signaling," Oxidative Medicine and Cellular Longevity, vol. 2021, Article ID 6645005, 17 pages, 2021.

[156] Z.-L. Wu, Q.-Q. Xie, T.-C. Liu, X. Yang, G.-Z. Zhang, and H.-H. Zhang, "Role of the Wnt pathway in the formation, development, and degeneration of intervertebral discs," Pathology-Research and Practice, vol. 220153366 pages, 2021.

[157] A. J. Chakraborty, S. Mitra, T. E. Tallei et al., "Bromelain a potential bioactive compound: a comprehensive overview from a pharmacological perspective," Life, vol. 11, no. 4, 317 pages, 2021.

[158] O. Goni, M. F. Khan, M. M. Rahman et al., "Pharmacological insights on the antidepressant, anxiolytic and aphrodisiac potentials of Aglaonema hookerianum Schott," Journal of Ethnopharmacology, vol. 268, Article ID 113664, 2021. 